\title{
Fossil and non-fossil source contributions to atmospheric carbonaceous aerosols during extreme spring grassland fires in Eastern Europe
}

\author{
Vidmantas Ulevicius ${ }^{1}$, Steigvilè Byčenkiené ${ }^{1}$, Carlo Bozzetti ${ }^{2}$, Athanasia Vlachou ${ }^{2}$, Kristina Plauškaitė ${ }^{1}$, \\ Genrik Mordas $^{1}$, Vadimas Dudoitis ${ }^{1}$, Gülcin Abbaszade ${ }^{3}$, Vidmantas Remeikis ${ }^{1}$, Andrius Garbaras ${ }^{1}$, \\ Agne Masalaite $^{1}$, Jan Blees ${ }^{2}$, Roman Fröhlich ${ }^{2}$, Kaspar R. Dällenbach ${ }^{2}$, Francesco Canonaco ${ }^{2}$, Jay G. Slowik ${ }^{2}$, \\ Josef Dommen $^{2}$, Ralf Zimmermann ${ }^{3,4}$, Jürgen Schnelle-Kreis ${ }^{3}$, Gary A. Salazar ${ }^{5}$, Konstantinos Agrios ${ }^{5,6}$, \\ Sönke Szidat ${ }^{5}$, Imad El Haddad ${ }^{2}$, and André S. H. Prévôt ${ }^{2}$ \\ ${ }^{1}$ Department of Environmental Research, SRI Center for Physical Sciences and Technology, Vilnius, 10222, Lithuania \\ ${ }^{2}$ Laboratory of Atmospheric Chemistry, Paul Scherrer Institute (PSI), Villigen, 5232, Switzerland \\ ${ }^{3}$ Helmholtz Zentrum München, German Research Center for Environmental Health (GmbH), Joint Mass Spectrometry \\ Centre, Cooperation Group Comprehensive Molecular Analytics and Helmholtz Virtual Institute of Complex Molecular \\ Systems in Environmental Health - Aerosol and Health (HICE), Neuherberg, 85764, Germany \\ ${ }^{4}$ Analytical Chemistry \& Joint Mass Spectrometry Centre, Institute of Chemistry, University of Rostock, Dr.-Lorenz-Weg 1, \\ Rostock, 18051, Germany \\ ${ }^{5}$ Department of Chemistry and Biochemistry \& Oeschger Centre for Climate Change Research, University of Bern, Bern, \\ 3012, Switzerland \\ ${ }^{6}$ Laboratory of Radiochemistry, PSI, Villigen, 5232, Switzerland
}

Correspondence to: Vidmantas Ulevicius (ulevicv@ktl.mii.lt) and André S. H. Prévôt (andre.prevot@psi.ch)

Received: 15 July 2015 - Published in Atmos. Chem. Phys. Discuss.: 29 September 2015

Revised: 1 April 2016 - Accepted: 9 April 2016 - Published: 4 May 2016

\begin{abstract}
In early spring the Baltic region is frequently affected by high-pollution events due to biomass burning in that area. Here we present a comprehensive study to investigate the impact of biomass/grass burning (BB) on the evolution and composition of aerosol in Preila, Lithuania, during springtime open fires. Non-refractory submicron particulate matter $\left(\mathrm{NR}-\mathrm{PM}_{1}\right)$ was measured by an Aerodyne aerosol chemical speciation monitor (ACSM) and a source apportionment with the multilinear engine (ME-2) running the positive matrix factorization (PMF) model was applied to the organic aerosol fraction to investigate the impact of biomass/grass burning. Satellite observations over regions of biomass burning activity supported the results and identification of air mass transport to the area of investigation. Sharp increases in biomass burning tracers, such as levoglucosan up to $683 \mathrm{ng} \mathrm{m}^{-3}$ and black carbon (BC) up to $17 \mu \mathrm{g} \mathrm{m}^{-3}$ were observed during this period. A further separation between fossil and non-fossil primary and secondary contributions
\end{abstract}

was obtained by coupling ACSM PMF results and radiocarbon $\left({ }^{14} \mathrm{C}\right)$ measurements of the elemental (EC) and organic (OC) carbon fractions. Non-fossil organic carbon $\left(\mathrm{OC}_{\mathrm{nf}}\right)$ was the dominant fraction of $\mathrm{PM}_{1}$, with the primary $\left(\mathrm{POC}_{\mathrm{nf}}\right)$ and secondary $\left(\mathrm{SOC}_{\mathrm{nf}}\right)$ fractions contributing $26-44 \%$ and $13-$ $23 \%$ to the total carbon (TC), respectively. 5-8\% of the TC had a primary fossil origin $\left(\mathrm{POC}_{\mathrm{f}}\right)$, whereas the contribution of fossil secondary organic carbon $\left(\mathrm{SOC}_{\mathrm{f}}\right)$ was 4-13\%. Nonfossil $\mathrm{EC}\left(\mathrm{EC}_{\mathrm{nf}}\right)$ and fossil $\mathrm{EC}\left(\mathrm{EC}_{\mathrm{f}}\right)$ ranged from $13-24$ and $7-13 \%$, respectively. Isotope ratios of stable carbon and nitrogen isotopes were used to distinguish aerosol particles associated with solid and liquid fossil fuel burning. 


\section{Introduction}

On a global scale wood or grass burning is a major source of organic aerosol (Crutzen et al., 1979; Levine, 1996). Approximately $90 \%$ of vegetation burning is caused by humaninduced fires (Baldini et al., 2002) and only a minor fraction derives from natural processes such as lightning. The composition of biomass smoke depends on the type of wood, combustion conditions (flaming versus smoldering), and ambient weather conditions (Weimer et al., 2008; Grieshop et al., 2009; Hawkins and Russell, 2010 and Akagi et al., 2012). Fine particles emitted from biomass burning include directly emitted primary particles (POA) and secondary organic aerosols (SOA), formed in the atmosphere as the plume ages through photochemical processes driven by sunlight (Capes et al., 2008; Heringa et al., 2011).

Many studies have revealed that organic matter (OM) is the largest fraction of ambient fine particles, typically comprising 20-90\% of the submicron particulate mass (Jimenez et al., 2009). Factor analysis of aerosol mass spectra from the Aerodyne aerosol mass spectrometer enables the deconvolution of OM into different factors based on their mass spectral fingerprints (Lanz et al., 2007; Aiken et al., 2009; Ulbrich et al., 2009). Such results provided valuable insights into the source and transformation processes of organic aerosols (OA) in the atmosphere (Lanz et al., 2010; Ng et al., 2011; Hildebrandt et al., 2011; Canonaco et al., 2013; Bougiatioti et al., 2014; Huang et al., 2014).

The main type of biomass burning in Lithuania and surrounding countries in early spring during the last years is illegal grass burning for land clearing (Ulevicius et al., 2010b; Byčenkiené et al., 2013). The north-east European countries are considered to influence significantly the microphysical, chemical and optical properties of the aerosol in the Baltic Sea region (Kikas et al., 2008; Zawadzka et al., 2013; Mann et al., 2014; Beddows et al., 2014). Long-term measurements of carbonaceous aerosols performed in this area by Ulevicius et al. $(2010 \mathrm{a}, \mathrm{b})$ and Byčenkiene et al. $(2011,2013)$ reported a yearly occurrence of high biomass burning organic aerosol (BBOA) levels during March-April related to regional transport from the Kaliningrad region, Ukraine and the southwestern part of Russia surrounding the Black Sea, but information on the nature and chemical composition of the biomass burning aerosol in Lithuania is still limited. There has been no systematic investigation of the impact of biomass burning on ambient organic aerosol levels in this region, and a quantitative estimate is needed to understand the possible impacts of BBOA on air quality in the south-eastern Baltic Sea region.

In many studies levoglucosan was used to assess the contribution of biomass-burning smoke to the aerosol mass concentrations (Puxbaum et al., 2007; Herich et al., 2014). A number of source emission studies reported that levoglucosan is not a useful tracer after long-range transport due to its transformation (Hoffmann et al., 2010; Hennigan et al., 2010; Mochida et al., 2010). In contrast to levoglucosan, determination of radiocarbon $\left({ }^{14} \mathrm{C}\right)$ offers a unique possibility for source apportionment of carbonaceous aerosol particles, as it unambiguously distinguishes fossil from non-fossil emissions (e.g., Currie, 2000; Ceburnis et al., 2011).

For this study, in the framework of the Lithuanian-Swiss Cooperation Programme joint research project (AEROLIT), an aerosol chemical speciation monitor (ACSM) was deployed in a background area of the South Baltic Sea to measure airborne submicron particles for 1 month during a period of frequent grass burning pollution. The main findings include investigation of OA components (Sects. 3.1-3.2), molecular markers (Sect. 3.2), source apportionment of elemental and organic carbon (EC and OC) using ${ }^{14} \mathrm{C}$ data and positive matrix factorization (PMF) of the ACSM organic mass spectra (Sect. 3.3).

\section{Methods}

\subsection{Site description and filter sampling}

Continuous air monitoring and time integrated particulate matter sampling were carried out in March 2014 in Preila, Lithuania $\left(55^{\circ} 55^{\prime} \mathrm{N}, 21^{\circ} 04^{\prime} \mathrm{E} 5 \mathrm{~m}\right.$ a.s.l.) (Fig. 1). Preila is a representative coastal background site, an ideal location for studying the long-range transport of air pollutants in the South-eastern Baltic region due to the absence of significant local sources (Fig. 1, Table 1). It served as a "super site" for the EUSAAR-EU-funded (Integrated Infrastructures Initiatives) project. During the measurement period, strong biomass burning activities were observed on 9-10 March 2014. A high-volume sampler (Digital model Aerosol Sampler DHA-80, 500 $\mathrm{L} \mathrm{min}^{-1}$ ) was used to collect $\mathrm{PM}_{1}$ aerosol particles onto $150 \mathrm{~mm}$ diameter Pallflex quartz fibre filters (pre-baked for $24 \mathrm{~h}$ at $550^{\circ} \mathrm{C}$ ) over a $24 \mathrm{~h}$ sampling period. Filters were stored in a freezer $\left(\right.$ at $\left.-20^{\circ} \mathrm{C}\right)$ immediately after sampling.

\subsection{Instrumentation}

\subsubsection{Aerosol Chemical Speciation Monitor and data analysis}

An ACSM (Aerodyne Research, Inc., Billerica, MA, USA) was deployed to measure $\mathrm{PM}_{1}$ components in Preila (Fig. 1, Sect. 2.1). A PM 10 impactor-type inlet was utilized to remove coarse particles from the sample stream. The sampling air $\left(1.1 \mathrm{~L} \mathrm{~min}^{-1}\right)$ passed through a vertical $2.5 \mathrm{~m}$ long stainless steel tube with a $6 \mathrm{~mm}$ i.d. and a Nafion dryer (MD-110-12S4, PermaPure LLC, Toms River, NJ, USA) before reaching the device. Aerosol particle diffusion losses in the sampling line were less than $4.0 \%$ for particles from $40 \mathrm{~nm}$ to $1 \mu \mathrm{m}$ according to Gormley and Kennedy (Baron and Willike, 2001) and the relative humidity lower than $50 \%$ (by SATO model SK-L200TH). Thus, the used sampling line and ambient relative humidity did not affect aerosol mass concentration mea- 

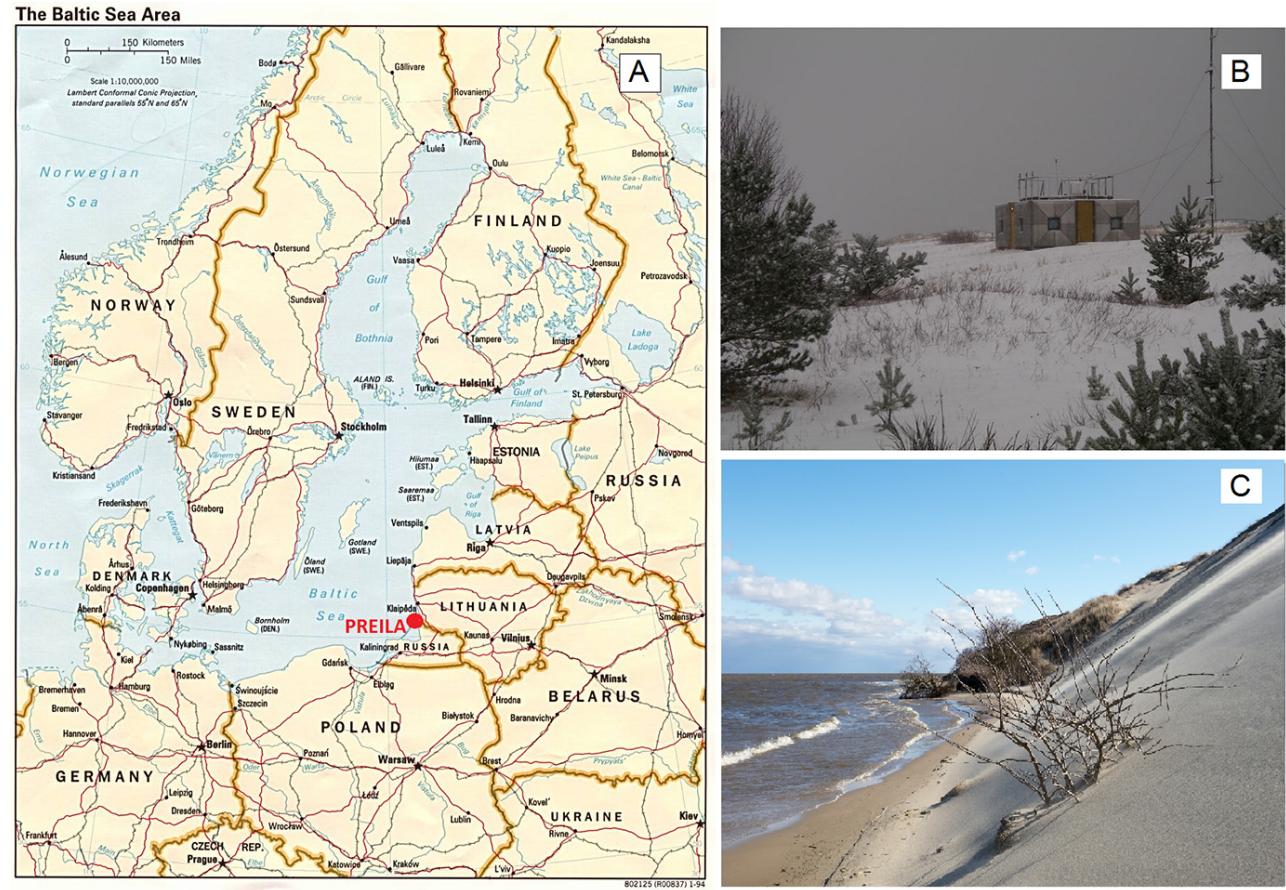

Figure 1. (a) Map of the observation site, Preila (indicated by the red mark). Nearest major cities are Klaipeda (40 km north) and Kaliningrad (90 km south), (b) Environmental pollution research station Preila and site surroundings (c).

Table 1. Preila site surroundings $10 \mathrm{~km}$.

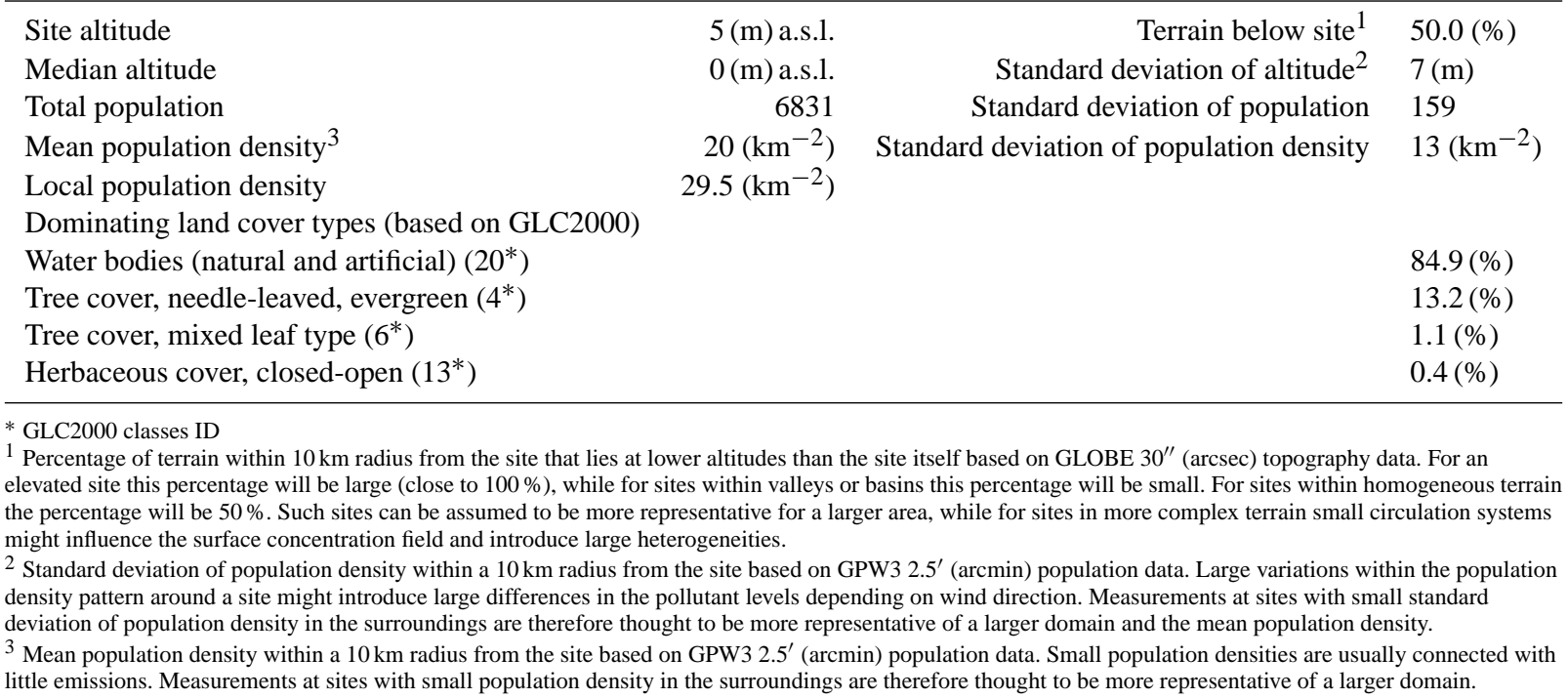

sured by ACSM. The transported aerosol flow was split and directed to a scanning mobility particle sizer (model 19.3.09 IFT/TT (TROPOS, Leipzig, Germany) and to the ACSM. In the ACSM particles were directed onto a resistively heated surface at $\sim 600{ }^{\circ} \mathrm{C}$ where NR-PM 1 components are flash vaporized and the resulting gases are subsequently ionized by $70 \mathrm{eV}$ electron impact. ACSM was operated with a time resolution of $\sim 28 \mathrm{~min}$ (for typical aerosol loadings, i.e., sev- eral $\mu \mathrm{g} \mathrm{m}^{-3}$ ) and a scan rate of $220 \mathrm{~ms} \mathrm{amu}^{-1}$ from $\mathrm{m} / z 10$ to 140 (approximately $31.9 \mathrm{~s}$ per scan and $1.126 \mathrm{~s}$ pause), 56 scans and data interval $30 \mathrm{~min}$. The data acquisition software used was DAQ 1.4.4.4. The mass concentrations and mass spectra were processed using ACSM standard data analysis software (v 1.5.3.0).

The instrument was calibrated using ammonium sulphate and ammonium nitrate. The determined calibration parame- 
ters were response factor $(\mathrm{RF}) \mathrm{RF}_{\mathrm{NO}_{3}}=2.75 \times 10^{-11}$ and relative ionization efficiency (RIE) $\mathrm{RIE}_{\mathrm{NH}_{4}}=6.16, \mathrm{RIE}_{\mathrm{SO}_{4}}=$ 0.92. The $\mathrm{RIE}_{\mathrm{Org}}=1.4, \mathrm{RIE}_{\mathrm{Chl}}=1.3$ were set as default. However, the ACSM collection efficiency varies depending on the acidity of aerosol particles, aerosol composition, and particle phase water (Matthew et al., 2008). Many atmospheric aerosol studies reported reasonable agreement and linear correlations were obtained with other measurements by using a collection efficiency of 0.5 (Aiken et al., 2009; Timonen et al., 2010). Middlebrook et al. (2012) had proposed a collection efficiency calculation method. The collection efficiency for each measurement and daily mean $\mathrm{CE}$ values were calculated. The $\mathrm{CE}$ variation was small during the entire measurement campaign (March, 2014), so the determined mean CE value was 0.52 with a standard deviation of 0.08 , which is very close to other studies (Aiken et al., 2009; Timonen et al., 2010). This is not surprising because the sampled aerosol was dried to $\mathrm{RH}<50 \%$; moreover, the nitrate fraction was quite low (15\% on average) and a high acidity of aerosols was not expected at Preila station (EMEP, 2015). Thus, we used the $\mathrm{CE}=0.52$ in our investigation. The time series of organic aerosol mass spectra were processed using PMF analysis.

\subsubsection{PMF analysis}

The ACSM measured data were averaged to $1 \mathrm{~h}$ time resolution. A graphical user interface SoFi (Source Finder) (Canonaco et al., 2013), developed at Paul Scherrer Institute was used to perform PMF for the source apportionment of the non-refractory OA mass spectra collected during March 2014. Only signals at $m / z<120$ were used for PMF analysis (Paatero and Tapper, 1994; Paatero, 1997) due to the following reasons: (1) the signals above $m / z>120$ account for a minor fraction of total signal, (2) the $m / z$ 's $>120$ have larger uncertainties because of poor ion transmission and the large interferences of naphthalene signals on some $m / z$ 's (e.g., $m / z 127,128$, and 129) (Sun et al., 2012). A 2factor solution including a Primary Organic Aerosol factor (POA), and a Secondary Organic Aerosol factor (SOA) was selected for this study. Twenty different PMF runs were performed using a bootstrapping approach (Davison and Hinkley, 1997). The bootstrap creates new input data matrices by randomly resampling measured mass spectra from the original input matrices. Moreover, each PMF bootstrap run is initiated from a different pseudorandom starting-point of the algorithm (seed). The bootstrapping approach, together with the seed approach allows a reasonable exploration of the PMF solution space (Paatero et al., 2014). Higher order solutions (3 factors) were explored yielding additional primary profiles, without a significant modification of the secondary contributions. Moreover the retrieved additional profiles showed very high time correlation $\left(R^{2}=0.98\right)$ with the POA factor, suggesting a splitting of the same aerosol source. As the additional primary factors could not be associated to specific primary emissions, those solutions are not shown. Medium-long range transport of polluted air masses resulted in a co-variability of the sources at the sampling site, hampering a further separation of the primary organic aerosols.

\subsubsection{Seven-wavelength aethalometer and Scanning Mobility Particle Sizer}

An aethalometer, Model AE31 Spectrum (Manufactured by Aerosol d.o.o., Ljubljana, Slovenia) provided continuous measurements of the black carbon (BC) mass concentrations. The aethalometer was equipped with a $\mathrm{PM}_{2.5}$ impactor. The aethalometer data were recorded with a 5-min time resolution. The optical transmission of light absorbing carbonaceous aerosol particles was measured at seven wavelengths $(370,450,520,590,660,880$, and $950 \mathrm{~nm})$. Measurements at $880 \mathrm{~nm}$ wavelength were used to determine BC mass concentration (Lavanchy et al., 1999). The aethalometer converts light attenuation measurements to $\mathrm{BC}$ mass using a specific attenuation absorption cross-section $(\sigma)$ of $16.6 \mathrm{~m}^{2} \mathrm{~g}^{-1}$ (at $880 \mathrm{~nm}$ ) (Aethalometer Operations manual). The default value for the near-infrared wavelength of $880 \mathrm{~nm}$ was set by the manufacturer. An empirical algorithm for loading effects compensation was used (Collaud Coen et al., 2010). The Ångström exponent of the absorption coefficient computed by fitting an exponential curve was evaluated.

Aerosol size distribution measurements were performed using a Scanning Mobility Particle Sizer (SMPS) model 19.3.09 IFT/TT (TROPOS, Leipzig, Germany), with automatic sheath flow, temperature and relative humidity $(\mathrm{RH})$ control (SMPS setup V2.6 TT 2006) as described in Wiedensohler et al. (2012) applying a CPC UF-02M (Mordas et al., 2013). The SMPS measured particle size ( 8.7 to $840.0 \mathrm{~nm}$ ) with a time resolution of 5 min having 72 channels.

\subsubsection{OC / EC, ${ }^{14} \mathrm{C}, \delta^{13} \mathrm{C}$ and $\delta^{15} \mathrm{~N}$ analysis}

Filter measurements were performed to determine OC, EC and total carbon (TC) concentrations with a thermo-optical OC / EC analyser (Sunset Laboratory Inc, USA) equipped with a non-dispersive infrared (NDIR) detector. A $1.5 \mathrm{~cm}^{2}$ filter punch was analyzed according to the EUSAAR2 protocol (Cavalli et al., 2010). The blank filter was subtracted only from the measured OC and TC concentrations, as for the EC the corresponding blank was below the detection limit of the instrument.

${ }^{14} \mathrm{C}$ in $\mathrm{EC}$ and $\mathrm{TC}$ was measured using the accelerator mass spectrometer MICADAS, equipped with a gas-capable ion source (Szidat et al., 2014). ${ }^{14} \mathrm{C}$ analysis of TC was determined after combustion of filter punches in an elemental analyser, directly coupled to the MICADAS (Salazar et al., 2015). The $\mathrm{TC}{ }^{14} \mathrm{C}$ raw data were corrected for a representative field blank. For ${ }^{14} \mathrm{C}$ analysis of $\mathrm{EC}$, the filters were first water extracted in order to minimize charring by removing the water-soluble OC (WSOC). Then the Swiss_4S protocol 
(Zhang et al., 2012) was used to remove the water-insoluble $\mathrm{OC}$ (WINSOC) and measure the $\mathrm{EC}^{14} \mathrm{C}$, by coupling of the Sunset instrument to the MICADAS (Agrios et al., 2015). ${ }^{14} \mathrm{C}$ in $\mathrm{OC}$ was determined from the $\mathrm{TC}{ }^{14} \mathrm{C}$ and the $\mathrm{EC}{ }^{14} \mathrm{C}$ results with an isotope mass balance calculation. All the data from the ${ }^{14} \mathrm{C}$ analysis were corrected for the decay of the ${ }^{14} \mathrm{C}$ from 1950 until present. The reported uncertainty for the non-fossil fraction of EC includes both charring of OC (overestimation of EC) and EC loss (underestimation of EC) during the WINSOC removal process (Zhang et al., 2012). Nonfossil fractions of TC, $\mathrm{EC}$ and $\mathrm{OC}$ (i.e., $\mathrm{TC}_{\mathrm{nf}}, \mathrm{EC}_{\mathrm{nf}}$ and $\mathrm{OC}_{\mathrm{nf}}$ ) were determined from the individual ${ }^{14} \mathrm{C}$ analyses and ${ }^{14} \mathrm{C}$ reference values. These reference values represent emissions from purely non-fossil sources and amount to $1.06 \pm 0.03$ for TC and $\mathrm{OC}$ and $1.10 \pm 0.03$ for EC based on the calculation of Mohn et al. (2008). The fossil fractions of TC, EC and OC (i.e., $\mathrm{TC}_{\mathrm{f}}, \mathrm{EC}_{\mathrm{f}}$ and $\mathrm{OC}_{\mathrm{f}}$ ) were determined by subtraction of the respective non-fossil fractions.

Bulk $\delta^{13} \mathrm{C}$ and $\delta^{15} \mathrm{~N}$ values were derived by measuring filter pieces $\left(1.4 \mathrm{~cm}^{2}\right)$ wrapped in tin capsules $(8 \times 5 \mathrm{~mm}$, Elemental Microanalysis) using an elemental analyser accompanying an isotope ratio mass spectrometer (EA-IRMS, Flash EA1112 - Thermo V Advantage) via a ConFlo III interface. The autosampler of the EA was continuously flushed with $\mathrm{He}\left(180 \mathrm{~mL} \mathrm{~min}^{-1}\right)$ to remove all atmospheric gases. Helium flow on the oxidation column was $80 \mathrm{~mL} \mathrm{~min}^{-1}$. Flash combustion occurred in the oxidation column with the presence of $\mathrm{O}_{2}$ (the $\mathrm{O}_{2}$ flow was $180 \mathrm{~mL} \mathrm{~min}^{-1}$ for $4 \mathrm{~s}$ ). Formed gases were taken to the reduction column in which molecular nitrogen was obtained from any nitrogen oxides followed by a water trap (magnesium perchlorate). The nitrogen and the carbon dioxide were separated on a packed gas chromatographic (GC) column (PoraPlot, $3 \mathrm{~m} \times 2 \mathrm{~cm}, 35^{\circ} \mathrm{C}$ ) and delivered to the isotope ratio mass spectrometer (via the ConFlo interface) where the measurement of carbon and nitrogen isotope ratio was made. The amount of nitrogen and carbon in the sample was determined by a thermal conductivity detector which is a part of the elemental analyser. These measurements were used in the isotope mass balance calculations (Eq. 1).

The total carbon and total nitrogen fractions of the aerosol particles were used for the isotopic ratio measurements. Stable carbon and nitrogen isotopic ratio measurements were expressed relative to the Vienna Pee Dee Belemnite (VPDB) standard using the formula:

$\delta^{13} \mathrm{C}=\left(R_{\text {sample }} / R_{\text {sample }}-1\right) \times 1000(\% o)$,

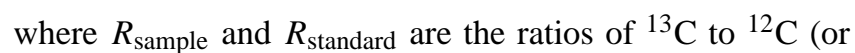
${ }^{15} \mathrm{~N}$ to ${ }^{14} \mathrm{~N}$ ) in the sample and the standard (referred to as VPDB), respectively.

Repeated analysis of certified reference material (caffeine IAEA-600) and oil (NBS 22) gave an average $\delta^{13} \mathrm{C}$ value: mean $\pm \sigma=-27.77 \pm 0.08 \%$ (certified value: mean $\pm \sigma=$ $-27.771 \pm 0.043 \%$ ovPB $)$ and $-30.03 \pm 0.09 \%$ (certified value: mean $\pm \sigma=-30.031 \pm 0.043 \%$ ovPDB), respectively. These values were used for $\delta^{13} \mathrm{C}$ measurements in order to evaluate an analytical precision and calibration of a reference gas $\left(\mathrm{CO}_{2}\right)$ to VPDB. Meanwhile, the IAEA-600 standard gave an average $\delta^{15} \mathrm{~N}$ value: mean $\pm \sigma=1.0 \pm 0.2 \%$ o which was used for calibration of a reference gas $\left(\mathrm{N}_{2}\right)$ to air (for $\delta^{15} \mathrm{~N}$ measurements).

Stable carbon and nitrogen isotope ratios were measured in the samples with the signal intensity reaching $1000 \mathrm{mV}$ or more, due to analytical restrictions (the isotope values measurements below $1000 \mathrm{mV}$ did not fulfil linearity requirements of $0.07 \% / \mathrm{V}$ for the internal standard).

The mass balance equation was used to calculate the real $\delta$ values of carbon or nitrogen of the aerosol samples (blank correction):

$m_{\text {measured }} \times \delta X_{\text {measured }}=m_{\text {real }} \times \delta X_{\text {real }}+m_{\text {blank }} \times \delta X_{\text {blank }}$,

where $m_{\text {measured }}$ was the mass of measured material (carbon or nitrogen) in the measured sample, $\delta X_{\text {measured }}$ was the measured (aerosol + filter) $\delta$ value (carbon or nitrogen), $m_{\text {real }}$ was the mass of real aerosol material (carbon or nitrogen), $\delta X_{\text {real }}$ was the isotope ratio of the real aerosol material (carbon or nitrogen); $m_{\text {blank }}$ and $\delta X_{\text {blank }}$ were the mass and isotope ratio (of carbon or nitrogen) of the blank filter, respectively.

\subsubsection{Radiocarbon-based source apportionment of carbonaceous aerosols}

An estimate of fossil and non-fossil primary and secondary organic carbon $\left(\mathrm{POC}_{\mathrm{f}}, \mathrm{POC}_{\mathrm{nf}}, \mathrm{SOC}_{\mathrm{f}}, \mathrm{SOC}_{\mathrm{nf}}\right)$ was achieved by coupling ACSM-PMF results, ${ }^{14} \mathrm{C}$ data, and organic marker measurements using a chemical mass balance-like approach. The sensitivity of $\mathrm{POC}_{\mathrm{f}}, \mathrm{POC}_{\mathrm{nf}}, \mathrm{SOC}_{\mathrm{f}}$, and $\mathrm{SOC}_{\mathrm{nf}}$ contributions to the assumed parameters and measurement errors are described in details in this section. The approach is based on the $\mathrm{POC}_{\mathrm{nf}}$ estimate, for a subsequent determination of $\mathrm{SOC}_{\mathrm{nf}}, \mathrm{SOC}_{\mathrm{f}}$, and $\mathrm{POC}_{\mathrm{f}}$ as follows:

$\mathrm{SOC}_{\mathrm{nf}}=\mathrm{OC}_{\mathrm{nf}}-\mathrm{POC}_{\mathrm{nf}}$,

$\mathrm{SOC}_{\mathrm{f}}=\mathrm{SOC}-\mathrm{SOC}_{\mathrm{nf}}$,

$\mathrm{POC}_{\mathrm{f}}=\mathrm{OC}_{\mathrm{f}}-\mathrm{SOC}_{\mathrm{f}}$.

${ }^{14} \mathrm{C}$ measurements and ACSM-PMF results were coupled as follows. Daily $\mathrm{OC}_{\mathrm{nf}}$ measurements from radiocarbon analysis as well as average daily POA from ACSM-PMF results provided two upper boundaries for the daily $\mathrm{POC}_{\mathrm{nf}}$ contribution. In this manner we identified a possible daily range of $\mathrm{POC}_{\mathrm{nf}}$ contributions. In order to determine more precisely the $\mathrm{POC}_{\mathrm{nf}}$ daily contributions within the aforementioned possible daily ranges, we performed a sensitivity analysis. Briefly, in the sensitivity analysis we considered a uniform distribution of possible $\mathrm{POC}_{\mathrm{nf}}$ contributions within the identified possible daily ranges, meaning that each $\mathrm{POC}_{\mathrm{nf}}$ 
value in the selected ranges was considered as equally probable (however, as discussed in the next section, in order to explore the influence of this assumption we also performed the same sensitivity analysis assuming a non-uniform distribution). Assuming no $\mathrm{POC}_{\mathrm{nf}}$ contribution from other sources than biomass burning organic carbon (BBOC), each $\mathrm{POC}_{\mathrm{nf}}$ contribution in the acceptable daily ranges could be written either as $[\mathrm{BBOC}]=[$ levoglucosan $] / \alpha$ or as $[\mathrm{BBOC}]$ $=\left[\mathrm{EC}_{\mathrm{nf}}\right] / \beta$, where $\alpha$ represents the levoglucosan $/ \mathrm{BBOC}$ ratio and $\beta$ represents the $\mathrm{EC}_{\mathrm{nf}} / \mathrm{BBOC}$ ratio. In two separated sensitivity analyses we scanned broad $\alpha$ and $\beta$ ranges covering the possible $\mathrm{POC}_{\mathrm{nf}}$ daily ranges and we retained only $\mathrm{POC}_{\mathrm{nf}}$, [levoglucosan] $/ \alpha$, and $\left[\mathrm{EC}_{\mathrm{nf}}\right] / \beta$ combinations associated to selected acceptance criteria described in the following. From the acceptable solutions we then derived the daily probability distribution function of $\mathrm{POC}_{\mathrm{f}}, \mathrm{SOC}_{\mathrm{nf}}$, $\mathrm{SOC}_{\mathrm{f}}, \mathrm{POC}_{\mathrm{f}}, \alpha$, and $\beta$.

The assumption that each input $\mathrm{POC}_{\mathrm{nf}}$ contribution in the selected possible range is equally probable (hereafter referred to as "uniform distribution approach") has advantages and drawbacks: while this assumption does not consider any a priori information about levoglucosan $/ \mathrm{POC}_{\mathrm{nf}}$ and $\mathrm{EC}_{\mathrm{nf}} / \mathrm{POC}_{\mathrm{nf}}$, it considers those ratios as equally possible. To explore the influence of this assumption on our results we performed the same sensitivity analysis assuming an input levoglucosan $/ \mathrm{POC}_{\mathrm{nf}}$ distribution derived from 33 profiles for combustion of hard or softwoods in domestic fireplaces or woodstoves (Fine et al., 2001, 2002, 2004a, b; Schmidl et al., 2008, the approach is hereafter referred to as "non-uniform distribution approach"). We eventually derived the probability distribution functions of the levoglucosan $/ \mathrm{POC}_{\mathrm{nf}}$ and $\mathrm{EC}_{\mathrm{nf}} / \mathrm{POC}_{\mathrm{nf}}$ ratios relative to the acceptable solutions. The two approaches provided similar results. From the uniform distribution approach, a median levoglu$\operatorname{cosan} / \mathrm{POC}_{\mathrm{nf}}$ ratio of 0.18 (1st quartile $=0.14$; 3rd quartile $=0.23)$ and a median $\mathrm{EC}_{\mathrm{nf}} / \mathrm{POC}_{\mathrm{nf}}$ ratio of $0.32(1 \mathrm{st}$ quartile $=0.28 ; 3$ rd quartile $=0.36$ ) were retrieved, whilst from the non-uniform distribution approach a median levoglucosan $/ \mathrm{POC}_{\mathrm{nf}}$ ratio of 0.15 (1st quartile $=0.13 ; 3 \mathrm{rd}$ quartile $=0.18)$ and a median $\mathrm{EC}_{\mathrm{nf}} / \mathrm{POC}_{\mathrm{nf}}$ ratio of $0.33(1 \mathrm{st}$ quartile $=0.28 ; 3$ rd quartile $=0.36$ ) were obtained.

In the following section a technical description of the sensitivity analysis implementation is reported. For each filter sample $i, 10000$ random combinations $(r)$ of input data, $[\mathrm{TC}]_{i, \mathrm{r}},[\mathrm{EC}]_{i, \mathrm{r}},\left[\mathrm{EC}_{\mathrm{f}}\right]_{i, \mathrm{r}},\left[\mathrm{OC}_{\mathrm{f}}\right]_{i, \mathrm{r}}$, and $[\text { Levoglucosan }]_{i, \mathrm{r}}$, were generated. In this process, we assume a normal distribution of the errors around the average $[X]_{i}$ value ( $X$ being one of the input values mentioned above), and a distribution width equal to the standard deviation $\sigma[X]_{i}$.
For each random combination of input data, the corresponding $[\mathrm{OC}]_{i, \mathrm{r}},\left[\mathrm{EC}_{\mathrm{nf}}\right]_{i, \mathrm{r}}$, and $\left[\mathrm{OC}_{\mathrm{nf}}\right]_{i, \mathrm{r}}$ values were determined as

$$
\begin{aligned}
& {[\mathrm{OC}]_{i, \mathrm{r}}=[\mathrm{TC}]_{i, \mathrm{r}}-[\mathrm{EC}]_{i, \mathrm{r}},} \\
& {\left[\mathrm{EC}_{\mathrm{nf}}\right]_{i, \mathrm{r}}=[\mathrm{EC}]_{i, \mathrm{r}}-\left[\mathrm{EC}_{\mathrm{f}}\right]_{i, \mathrm{r}},} \\
& {\left[\mathrm{OC}_{\mathrm{nf}}\right]_{i, \mathrm{r}}=[\mathrm{OC}]_{i, \mathrm{r}}-\left[\mathrm{OC}_{\mathrm{f}}\right]_{i, \mathrm{r}} .}
\end{aligned}
$$

10000 random $[\mathrm{SOC}]_{\mathrm{S}}$ values were generated by randomly selecting a daily average $[\mathrm{SOA}]_{\mathrm{s}}$ value from one of the 20 ACSM-PMF runs $(s)$. The corresponding $[\mathrm{SOC}]_{\mathrm{s}}$ values were derived as

$[\mathrm{SOC}]_{\mathrm{S}}=[\mathrm{SOA}]_{\mathrm{s}} /(\mathrm{OM} / \mathrm{OC})_{\mathrm{SOA}_{\mathrm{s}}}$.

$(\mathrm{OM} / \mathrm{OC})_{\mathrm{SOA}_{\mathrm{s}}}$ and $\sigma(\mathrm{OM} / \mathrm{OC})_{\mathrm{SOA}_{\mathrm{s}}}$ were calculated according to Aiken et al. (2009) as function of the fractional contribution of the $m / z 44(f 44)$ to the $\mathrm{SOA}_{\mathrm{s}}$ mass spectra. Fröhlich et al. (2015) showed a systematic difference between $f 44$ measured from ACSM and AMS; therefore an empirical correction factor was accordingly applied to rescale $f 44$ from ACSM ( $\left.f 44_{\mathrm{ACSM}}\right)$ data to the corresponding AMS $f 44$ value ( $f 44_{\text {AMS }}$ ). The uncertainty relative to the $f 44$ correction factor was propagated into $\sigma(\mathrm{OM} / \mathrm{OC})_{\mathrm{SOA}_{s}}$ which includes the $\mathrm{O} / \mathrm{C}_{\mathrm{s}}$ uncertainty as well. Each $[\mathrm{SOC}]_{i, \mathrm{r}}$ value was obtained by randomly varying $[\mathrm{SOC}]_{\mathrm{s}}$ assuming a normal distribution of errors around the average value $[\mathrm{SOC}]_{\mathrm{s}}$ and a distribution width equal to $\sigma(\mathrm{OM} / \mathrm{OC})_{\mathrm{SOA}_{\mathrm{s}}}$. $[\mathrm{BBOC}]_{i, \mathrm{r}}$ contributions for each sample $i$ were derived as follows:

$[\mathrm{BBOC}]_{i, \mathrm{r}}=[\text { levoglucosan }]_{i, \mathrm{r}} / \alpha$,

$[\mathrm{BBOC}]_{i, \mathrm{r}}=\left[\mathrm{EC}_{\mathrm{nf}}\right]_{i, \mathrm{r}} / \beta$,

where $\alpha$ represents the levoglucosan / BBOC ratio. This ratio was systematically varied between 0.01 and 0.31 according to Huang et al. (2014) and references therein (scan step equals 0.01). $\beta$ corresponds to the $\mathrm{EC} / \mathrm{BBOC}$ ratio. Values of $\beta$ were systematically varied between 0.1 and 0.4 according to Zhang et al. (2015) and references therein (scan step equal to 0.01). $10000[\mathrm{BBOC}]_{i, \mathrm{r}, \alpha}$ and 10000 $[\mathrm{BBOC}]_{i, \mathrm{r}, \beta}$ were determined as in Eqs. (8) and (9). Only acceptable $[\mathrm{BBOC}]_{i, \mathrm{r}, \alpha / \beta}\left(=\left[\mathrm{POC}_{\mathrm{nf}}\right]_{i, \mathrm{r}, \alpha / \beta}\right)$ values were considered for the sensitivity analysis. The criteria to consider a $[\mathrm{BBOC}]_{i, \mathrm{r}, \alpha / \beta}$ value as acceptable were
(a) $[\mathrm{BBOC}]_{i, \mathrm{r}, \alpha / \beta} \leq[\mathrm{POC}]_{i, \mathrm{r}}$ and
(b) $[\mathrm{BBOC}]_{i, \mathrm{r}, \alpha / \beta} \leq\left[\mathrm{OC}_{\mathrm{nf}}\right]_{i, \mathrm{r}}$

$[\mathrm{POC}]_{i, \mathrm{r}}$ was determined as follows:

$[\mathrm{POC}]_{i, \mathrm{r}}=[\mathrm{OC}]_{i, \mathrm{r}}-[\mathrm{SOC}]_{i, \mathrm{r}}$

Only acceptable $[\mathrm{POC}]_{i, \mathrm{r}}$ values were considered. The criterion to consider a $[\mathrm{POC}]_{i, \mathrm{r}}$ value as acceptable was 


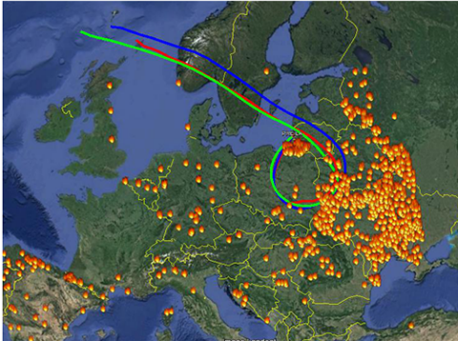

(a)

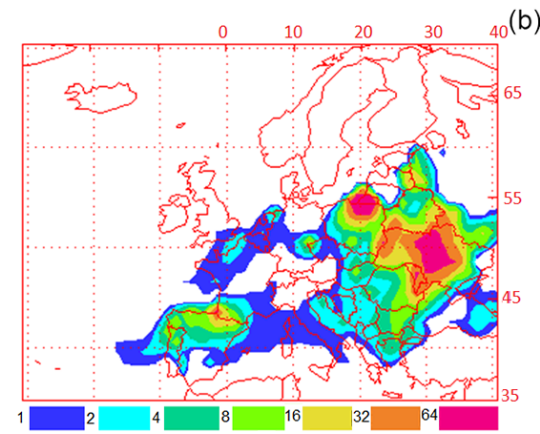

NCEP reanalysis surface level GrADS

$\mathrm{Pa}$

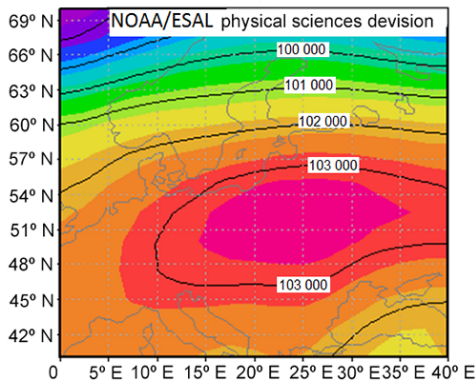

(c)

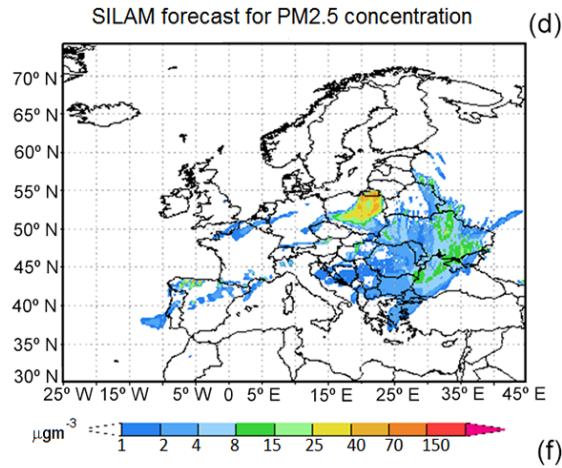

(e) (b)
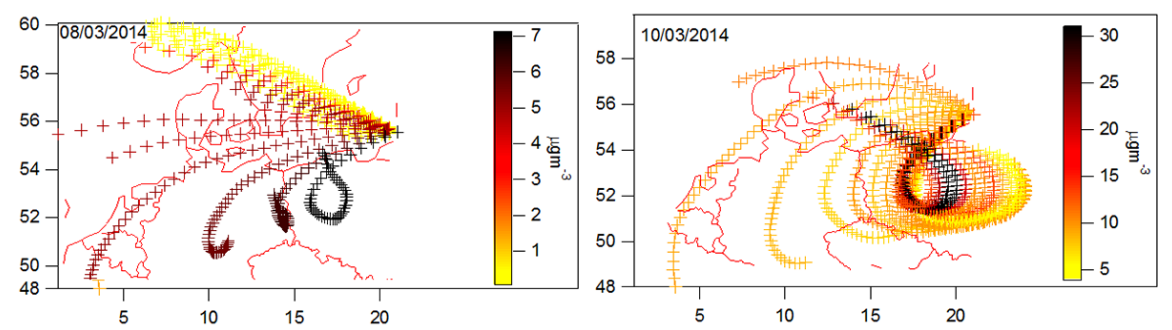

Figure 2. (a) Combined MODIS images observed from the Aqua satellite on 10 March 2014, showing numerous fires due to seasonal grass burning and $72 \mathrm{~h}$ air mass backward trajectories from the fire regions arriving at Preila at 100 (red), 200 (blue) and 500 (green) $\mathrm{m}$ above ground level (a.g.1.). (b) NAAPS model results showing surface smoke concentrations for the strongest stage (10 March 2014) (the color scale (from blue to purple) corresponds to the seven levels of the contours that indicate the smoke mass mixing ratio $\left(\mu \mathrm{g} \mathrm{m}{ }^{-3}\right.$ ) at the surface). Smoke optical depth at a wavelength of $0.55 \mu \mathrm{m}$. The contouring begins at $1 \mu \mathrm{g} \mathrm{m}^{-3}$ and doubles in magnitude for each successive contour. (c) Pressure level in $\mathrm{Pa}$ at the surface for $2.5^{\circ}$ latitude $\times 2.5^{\circ}$ longitude global grids (NCEP/NCAR Reanalysis $1,10 \mathrm{March}_{2014}$ ). (d) $\mathrm{PM}_{2.5}$ concentration $\left(\mu \mathrm{g} \mathrm{m}^{-3}\right)$ forecast utilized by the SILAM chemical transport model during the event of grass fires. (e, f) ACSM organics concentration $\left(\mu \mathrm{g} \mathrm{m}^{-3}\right.$ ) (measured in Preila) weighted air mass back trajectories of $48 \mathrm{~h}$ (for an arrival on 8 (e) and 10 (f) March 2014 ) with an altitude endpoint of $500 \mathrm{~m}$ a.g.l.

(c) $[\mathrm{POA}]_{\mathrm{s}} /[\mathrm{POC}]_{i, \mathrm{r}} \geq 1.3$ according to Mohr et al. (2009), Aiken et al. (2009).

$\left[\mathrm{SOC}_{\mathrm{nf}}\right]_{i, \mathrm{r}}$ values were then derived as

$\left[\mathrm{SOC}_{\mathrm{nf}}\right]_{i, \mathrm{r}}=\left[\mathrm{OC}_{\mathrm{nf}}\right]_{i, \mathrm{r}}-\left[\mathrm{POC}_{\mathrm{nf}}\right]_{i, \mathrm{r}}$

Only acceptable $\left[\mathrm{SOC}_{\mathrm{nf}}\right]_{i, \mathrm{r}}$ values were considered, where

(d) $\left[\mathrm{SOC}_{\mathrm{nf}}\right]_{i, \mathrm{r}} \leq[\mathrm{SOC}]_{i, \mathrm{r}}$

Only solutions where all 4 criteria (a), (b), (c), and (d) held were considered acceptable and retained.

Finally, $\left[\mathrm{SOC}_{\mathrm{f}}\right]_{i, \mathrm{r}}$ and $\left[\mathrm{POC}_{\mathrm{f}}\right]_{i, \mathrm{r}}$ were calculated as:

$\left[\mathrm{SOC}_{\mathrm{f}}\right]_{i, \mathrm{r}}=[\mathrm{SOC}]_{i, \mathrm{r}}-\left[\mathrm{SOC}_{\mathrm{nf}}\right]_{i, \mathrm{r}}$

$\left[\mathrm{POC}_{\mathrm{f}}\right]_{i, \mathrm{r}}=\left[\mathrm{OC}_{\mathrm{f}}\right]_{i, \mathrm{r}}-\left[\mathrm{SOC}_{\mathrm{f}}\right]_{i, \mathrm{r}}$

\subsubsection{Organic markers and satellite products}

Determination of organic marker concentrations was performed using a developed in situ derivatization thermal desorption gas chromatography time of flight mass spectrometry (IDTD-GC-MS) method (Orasche et al., 2011).

Biomass burning episodes were explored using a variety of remote-sensing data sets and their derived properties. Satellite data and ground-based observations of aerosol properties from the MODIS, HYSPLIT and SILAM (Sofiev et al., 2006) were coupled to analyze the variability of carbonaceous aerosols in Lithuania (Fig. 2). 
The MODIS sensors on-board NASA's Terra and Aqua satellites provide multiple thermal observations of the Earth on 9-10 March 2014 at a spatial resolution of $1 \mathrm{~km}$ using the latest version of the MODIS Active Fire Product (MOD14/MYD14) algorithm (MODIS, 2011). To identify the influence of air masses from different transport pathways on the large biomass burning (BB) event occurring at Preila, $72 \mathrm{~h}$ back trajectories at an arrival height of 100, 200 and $500 \mathrm{~m}$ were calculated by the Hybrid Single Particle Lagrangian Integrated Trajectory (HYSPLIT) Model Version 4.8 (Stein et al., 2015). All air mass back trajectories were generated using Gridded Meteorological Data archives of the Air Resource Laboratory (ARL), National Ocean and Atmospheric Administration (NOAA) (Fig. 2a).

The Navy Aerosol Analysis and Prediction System (NAAPS) model results were used to define the distribution of BB aerosols from wildfire areas (model description and results are available from the web pages of the Naval Research Laboratory, Monterey, CA, USA; http://www.nrlmry. navy.mil/aerosol/) (Fig. 2b). The NAAPS model has been adapted to combine real-time observations of biomass burning based on the joint Navy/NASA/NOAA Fire Locating and Modelling of Burning Emissions system (FLAMBE, http://www.nrlmry.navy.mil/aerosol/) (Reid et al., 2004). The method has proven helpful in previous studies of long-range and regional transport of smoke (Honrath et al., 2004). The resolution of $2.5^{\circ}$ longitude $\times 2.5^{\circ}$ latitude National Centers for Environmental Prediction (NCEP) reanalysis data (Kanamitsu et al., 2002) during the grass burning episode were analysed to illustrate the sub synoptic-scale weather feature among the biomass burning events over Lithuania issued every $6 \mathrm{~h}$ for March 2014 (Fig. 2c). SILAM is an air quality and emergency open code system (http://silam.fmi.fi/) providing $\mathrm{PM}_{2.5}$ emission maps by Eulerian dynamics and a combination of basic acid and ozone chemistry with inert particles for fire and anthropogenic primary PM emission to account for the fire-induced aerosol contribution (Fig. 2d).

\section{Results and discussion}

\subsection{Identification of grass burning event}

Massive active fires occurred throughout the Kaliningrad region (Russia), Belorussia and Ukraine (Fig. 2a) when a high atmospheric pressure system was situated over the study area, as illustrated in the weather map of Fig. 2c. The plumes from those fires covered a large area south of the Baltic region and were transported thousands of kilometers downwind affecting the background air in Lithuania (Fig. 2). Although the number of fires was similar to that in previous years, the impact of the fire events on the Lithuanian air quality was enhanced in March 2014 due to air mass transport of smoke entrained in deep convection by the large-scale circulation around the pressure maximum of the anticyclonic sys- tem (Fig. 2c). This is consistent with the relatively high concentrations of smoke reaching Preila as predicted by NAAPS (Fig. 2b).

The weather maps showed that the high concentration of pollutants during this BB event was caused by the anticyclonic large-scale movement, which persisted throughout the lower troposphere causing stagnant conditions and extended aerosol residence time.

\subsection{Investigation of $\mathrm{PM}_{1}$ composition and ambient concentrations of organic tracers}

The climatic conditions in West Europe as well as in the western part of Lithuania are a moderate warm climate dominating by air mass transport from Atlantic Ocean, leading to higher humidity. Annual mean temperature increases in west-east direction. The average temperature of March was $\sim 3-4{ }^{\circ} \mathrm{C}$. During the BB event (9-11 March) combustion products were spread over the study region by the large-scale atmospheric circulation processes. At the beginning of the BB episode, the wind speed was up to $3 \mathrm{~m} \mathrm{~s}^{-1}$ on average in the daytime of 9 March, causing weaker dilution of the pollutants while the $\mathrm{BC}$ concentration was higher than $12 \mu \mathrm{g} \mathrm{m}^{-3}$.

During the campaign, on average, organic aerosol $\left(46 \%, 3.2 \mu \mathrm{g} \mathrm{m}^{-3}\left(\sigma=4.8 \mu \mathrm{g} \mathrm{m}^{-3}\right)\right)$ constituted the major fraction of the NR-PM 1 aerosol concentration composition measured by ACSM with lower contributions of sulfate $\left(17 \%, 1.2 \mu \mathrm{g} \mathrm{m}^{-3}\left(\sigma=1.1 \mu \mathrm{g} \mathrm{m}^{-3}\right)\right)$, nitrate $\left(20 \%, 1.4 \mu \mathrm{g} \mathrm{m}^{-3}\left(\sigma=1.8 \mu \mathrm{g} \mathrm{m}^{-3}\right)\right)$, ammonium $(15 \%$, $\left.1.0 \mu \mathrm{g} \mathrm{m}^{-3}\left(\sigma=0.9 \mu \mathrm{g} \mathrm{m}^{-3}\right)\right)$, and chloride $\left(2 \%, 0.1 \mu \mathrm{g} \mathrm{m}^{-3}\right.$ $\left.\left(\sigma=0.3 \mu \mathrm{g} \mathrm{m}^{-3}\right)\right)$. The average composition of NR-PM showed similar dominance of organics to previous observations in Europe (e.g., Crippa et al., 2014). OA contribution to NR-PM $\mathrm{PM}_{1}$ was found to be much higher during the grass burning period $\left(61 \%, 8.6 \mu \mathrm{g} \mathrm{m}^{-3}\left(\sigma=5.0 \mu \mathrm{g} \mathrm{m}^{-3}\right)\right)$, followed by sulfate $\left(5 \%, 1.4 \mu \mathrm{g} \mathrm{m}^{-3}\left(\sigma=0.5 \mu \mathrm{g} \mathrm{m}^{-3}\right)\right)$, nitrate $\left(19 \%, 3.0 \mu \mathrm{g} \mathrm{m}^{-3}\left(\sigma=1.4 \mu \mathrm{g} \mathrm{m}^{-3}\right)\right)$, ammonium $(13 \%$, $\left.1.6 \mu \mathrm{g} \mathrm{m}^{-3}\left(\sigma=0.7 \mu \mathrm{g} \mathrm{m}^{-3}\right)\right)$, and chloride $\left(3 \%, 0.4 \mu \mathrm{g} \mathrm{m}^{-3}\right.$ $\left.\left(\sigma=0.3 \mu \mathrm{g} \mathrm{m}^{-3}\right)\right)$ (Fig. 5a).

The concentrations of the monosaccharide anhydrides together with those of OC and EC are presented in Fig. 3. It is evident that during the event, when grass burning was most intense, the levoglucosan concentration increased up to $680 \mathrm{ng} \mathrm{m}^{-3}$. That is substantially lower than values reported during the extreme event of August 2010 in Moscow - $3100 \mathrm{ng} \mathrm{m}^{-3}$ (Popovicheva et al., 2014) and is higher than values $\left(220-290 \mathrm{ng} \mathrm{m}^{-3}\right.$ ) reported during a major biomass burning episode over northern Europe in Helsinki (Saarikoski et al., 2007), while background values in Nordic rural background sites were found to be 2.1$9.8 \mathrm{ng} \mathrm{m}^{-3}$ (Yttri et al., 2011). Concentrations of mannosan varied from 3.1 to $68.0 \mathrm{ng} \mathrm{m}^{-3}$ and those of galactosan from 1.0 to $12.0 \mathrm{ng} \mathrm{m}^{-3}$. The levoglucosan to mannosan $(\mathrm{L} / \mathrm{M})$, levoglucosan to galactosan (L/G) and levoglucosan to OC $(\mathrm{L} / \mathrm{OC})$ ratios were used before to separate different $\mathrm{BB}$ 


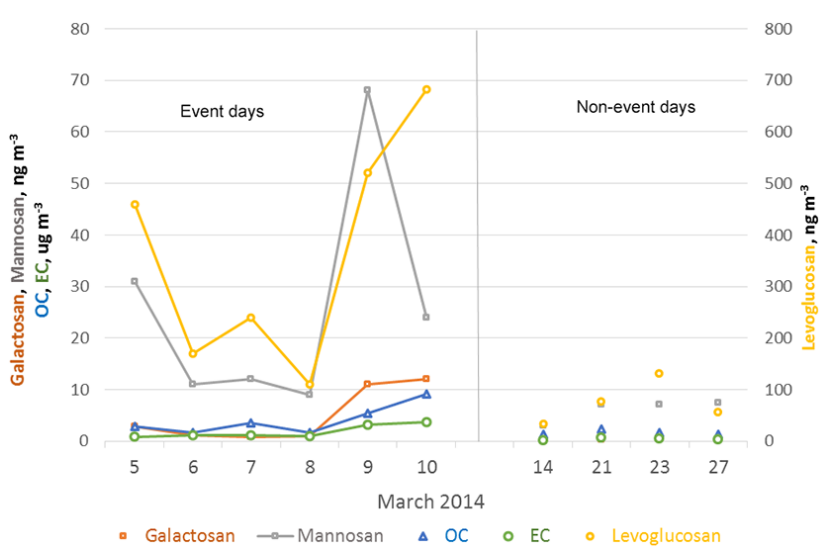

Figure 3. Average daily concentration during event days (from 5 to 10 March 2014) and non-event days (14, 21, 23 and 27 March 2014) for levoglucosan, galactosan, mannosan (in $\mathrm{n} \mathrm{m}^{-3}$ ) and for elemental carbon (EC) and organic carbon (OC) in $\mu \mathrm{g} \mathrm{m}^{-3}$.

sources (Fabbri et al., 2009; Oanh et al., 2011; Harrison et al., 2012). We measured average $\mathrm{L} / \mathrm{M}$ and $\mathrm{L} / \mathrm{G}$ ratios of 16.4 and 135.8 , respectively. This is similar to the values found by Orasche et al. (2012) from wood combustion in residential wood appliances and in the range of $\mathrm{L} / \mathrm{M}$ ratios reported (2.0-33.3) for grass fires by Oros et al. (2006). Excluding the strong event days of 9 and 10 March the sugars showed a good correlation with each other $\left(R^{2}>0.86\right)$. On 9 and 10 March the mannosan/galactosan was lower at $2-6$, indicating a different source than on the other days. Low mannosan/galactosan ratios were observed for grass and leaves (Sullivan et al., 2014). We observed an L to OC ratio from 0.06 to 0.16 during the biomass burning period and of $\sim 0.03$ during the days without biomass burning events. The values observed during biomass burning are in the range of those (0.04-0.20) reported for wildland fuels (Sullivan et al., 2008). The OC / EC ratio ranged from 1.5 to 6.2 being lower on event days (2.4-3.0) indicating an aerosol composition dominated by organic aerosol. During the intensive grass burning episode, consecutive new particle formation (NPF) events were observed. The observed NPF events could be attributed to the grass burning and secondary biomass burning product transformation as was evaluated in earlier studies over the same area (Ulevicius et al., 2010b). At 13:00, there was significant new particle formation on 9 and 10 March followed by subsequent growth up to $3 \mathrm{~h}$. A total particle number concentration with a daily mean value of $6440 \mathrm{~cm}^{-3}$ (with maximum value of $13000 \mathrm{~cm}^{-3}$ ) was observed, which was much higher than the daily mean observations in non-event days $\left(1660 \mathrm{~cm}^{-3}\right)$. In this area an annual mean total particle concentration of $2650 \mathrm{~cm}^{-3}$ was observed (Byčenkienė et al., 2013). Non-event days were characterized by bimodal (Aitken (geometric mean diameter $\left(D_{\mathrm{g}}\right)$ of $44 \mathrm{~nm})$ and accumulation $\left(D_{\mathrm{g}}=128 \mathrm{~nm}\right)$ ) distributions with a standard deviation of 1.68 and 1.87 , respectively. In com-

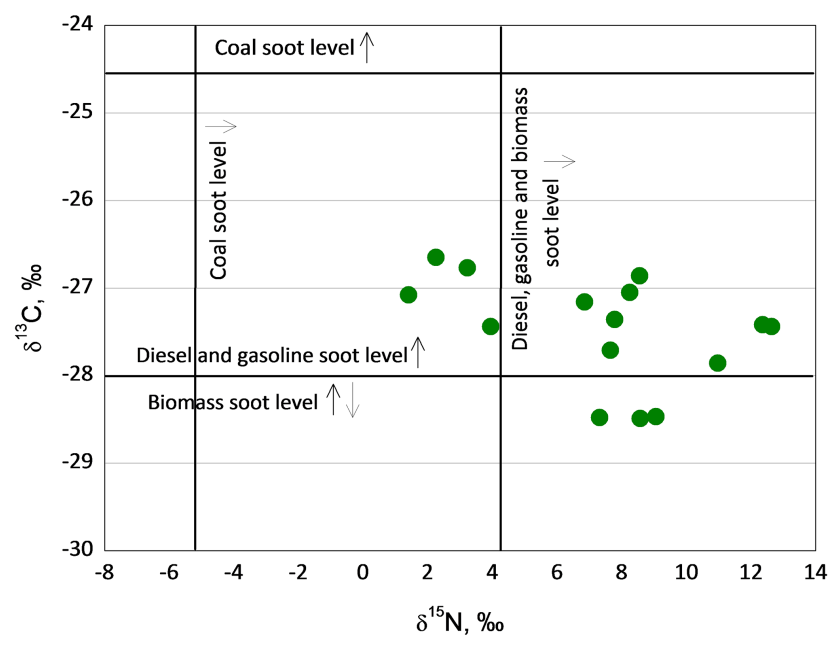

Figure 4. Stable carbon and nitrogen isotope ratio values of $\mathrm{PM}_{1}$ in Preila station. Vertical and horizontal lines represent carbon and nitrogen, respectively, isotope ratio characteristic values for the sources of aerosol particles (Garbaras et al., 2008, 2015; Ulevicius et al., 2010a; Widory, 2007).

parison, during the biomass burning event trimodal (nucleation $\left(D_{\mathrm{g}}=9.0 \mathrm{~nm}\right)$, Aitken $\left(D_{\mathrm{g}}=31.0 \mathrm{~nm}\right)$ and accumulation $\left.\left(D_{\mathrm{g}}=102 \mathrm{~nm}\right)\right)$ distributions with a standard deviation of $1.77,1.71$ and 1.68 , respectively. However, the volume distribution was characterized by a bimodal size distribution for the non-event days $\left(D_{\mathrm{g}}=330\right.$ and $\left.665 \mathrm{~nm}\right)$ and for the event day $\left(D_{\mathrm{g}}=250\right.$ and $\left.590 \mathrm{~nm}\right)$.

The measured $\delta^{13} \mathrm{C}$ values varied from -28.2 to $-26.7 \%$. The lowest stable carbon isotope ratio values $(-28.5 \%$ o were detected during the period with the highest total carbon concentration of $12.2 \mu \mathrm{g} \mathrm{m}^{-3}$ (10 March 2014) and $8.5 \mathrm{\mu g} \mathrm{m}^{-3}$ (9 March 2014). The highest concentration $14.0 \mathrm{\mu g} \mathrm{m}^{-3}$ of nitrogen was detected on 10 March 2014. The nitrogen isotope ratio values varied from +1.0 to $+13.0 \%$ o (Fig. 4).

Stable carbon and nitrogen isotope ratios values of aerosol particles derived from biomass burning (C3 plants) and liquid fossil fuel are overlapping (Garbaras et al., 2015; Masalaite et al., 2015; Turekian et al., 1998). Coal-derived aerosol particles are characterized by higher $\delta^{13} \mathrm{C}$ and lower $\delta^{15} \mathrm{~N}$ values (Fig. 4, solid lines). $\delta^{13} \mathrm{C}$ values of aerosol particles during wild grass burning events distinguish in low $\delta^{13} \mathrm{C}$ values (Garbaras et al., 2008; Ulevicius et. al., 2010b). The abovementioned distribution of $\delta^{13} \mathrm{C}$ and $\delta^{15} \mathrm{~N}$ values allowed excluding coal burning as main source for aerosol particles at Preila during the investigated event. Aerosol particles with $\delta^{13} \mathrm{C}$ values equal to $-28 \%$ and below originated mainly from grass burning events. This interpretation of the data is consistent with the radiocarbon analysis shown below. 

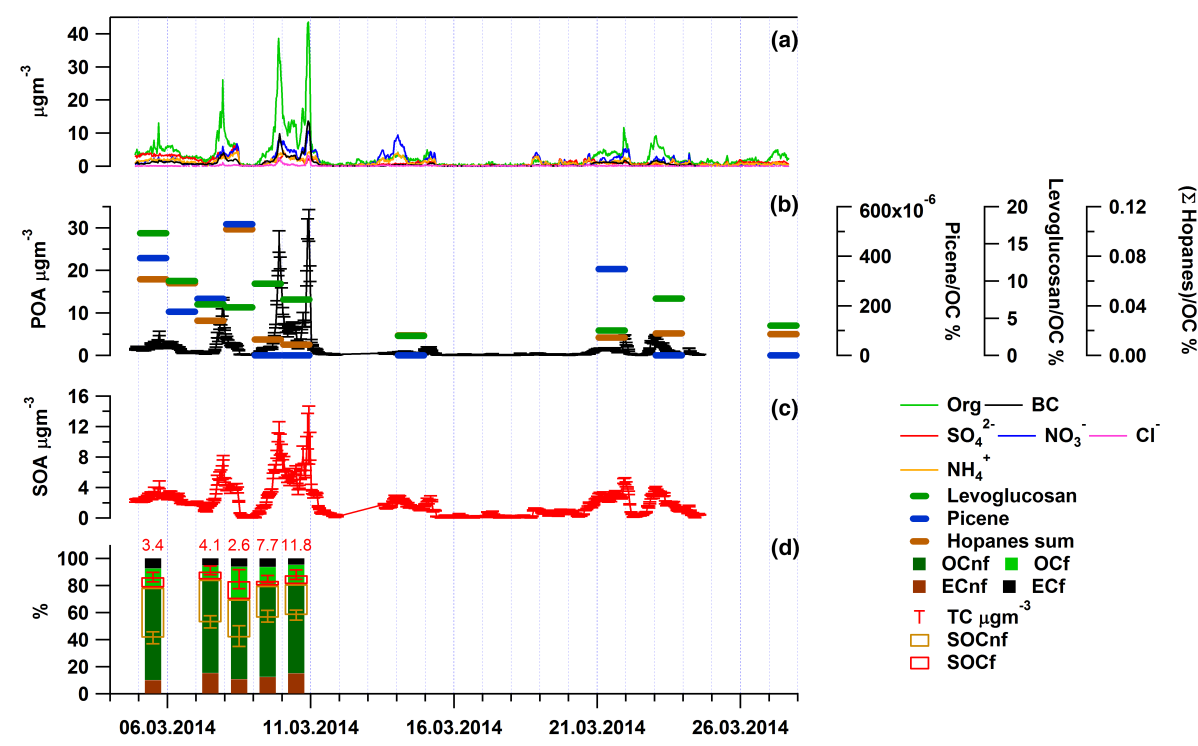

(c)

$$
\begin{aligned}
& -\mathrm{Org}-\mathrm{BC} \\
& -\mathrm{SO}_{4}{ }^{2-}-\mathrm{NO}_{3}{ }^{-}-\mathrm{Cl}^{-} \\
& -\mathrm{NH}_{4}{ }^{+}
\end{aligned}
$$

- Levoglucosan

- Picene

- Hopanes sum

- OCnf $\square$ OCf

T $\mathrm{TC}_{\mu \mathrm{gm}^{-3}}$

$\square$ SoCnf

$\square$ SOCf

Figure 5. Average chemical composition and time series of NR-PM 1 OA for the entire study, (a, b) time series of the POA factor and percent contribution of the corresponding tracer species (levoglucosan, picene and hopanes) to total OA, (c) time series of the SOA factor, (d) relative source apportionment of TC during the $\mathrm{BB}$ event. Numbers indicate the total carbon absolute concentrations in $\mu \mathrm{g} \mathrm{m}^{-3}$, variations of the mass concentrations of the $\mathrm{SOC}_{\mathrm{f}}$ and $\mathrm{SOC}_{\mathrm{nf}}$ (the whiskers above and below the boxes indicate the 1st and 3rd quartiles.

\subsection{Source apportionment of EC and $\mathrm{OC}$ using ${ }^{14} \mathrm{C}$ data}

Relative fossil and non-fossil contributions to OC and EC were evaluated using ${ }^{14} \mathrm{C}$ analysis (Szidat et al., 2014) to enable a more detailed source attribution of the carbonaceous aerosol mass. Widely used, two-source simple models (Currie, 2000; Lemire et al., 2002; Lewis et al., 2004; Szidat et al., 2004) can only distinguish fossil from non-fossil TC emissions. Here, carbonaceous aerosol was described to be composed of the following four categories: $\mathrm{OC}_{\mathrm{f}}$ and $\mathrm{EC}_{\mathrm{f}}$ attributed to primary and secondary fossil fuel combustion; and $\mathrm{OC}_{\mathrm{nf}}$, and $\mathrm{EC}_{\mathrm{nf}}$ typically attributed to primary and secondary biomass burning, cooking, biogenic emissions and non-fossil OC combustion (Table 2, Fig. 5). There was day-to-day variation in the fractional contributions to TC throughout the BB event. The fraction of elemental carbon from biomass burning $\mathrm{EC}_{\mathrm{bb}}\left(=\mathrm{EC}_{\mathrm{nf}}\right)$ to total $\mathrm{EC}$ was found to be on average $67 \pm 3 \%$. For $\mathrm{EC}_{\mathrm{bb}}$ the mean relative contribution to total carbon in background areas of Northern countries was found to be $<1.5 \%$ on non-event days (Yttri et al., 2011). It was also reported that a major peak in $\mathrm{EC}_{\mathrm{bb}}$ values between March and April was observed at the Zeppelin atmospheric observatory (Yttri et al., 2014). Observed high values are unusual and have only been found in wood burning dominated places like villages in Alpine valleys (Zotter et al., 2014). This shows, together with the high levels of levoglucosan, that biomass burning contributed to a large extent to $\mathrm{OC}_{\mathrm{nf}}$ during this event. A mean light absorption coefficient $\alpha_{370-950}$ (the absorption exponent calculated using the seven wavelengths Aethalometer) of $1.38(\sigma=0.11)$ was obtained during wildfires, which is higher than the mean $\alpha_{370-950}$ calculated for the non-event days $(1.13, \sigma=0.19)$ ). The light absorption exponent values were calculated with $\lambda=370-520 \mathrm{~nm}$ and $\lambda=590-950 \mathrm{~nm}$ wavelengths for comparison purpose. The mean values of $\alpha_{370-520}$ and $\alpha_{590-950}$ were found to be $1.53(\sigma=0.19)$ and $1.32(\sigma=0.09)$ during event days and $1.25(\sigma=0.27)$ and $1.13(\sigma=0.18)$ for the non-event days, respectively. In comparison, during a similar event in Preila higher mean values of $\alpha_{370-520}$ and $\alpha_{590-950} \mathrm{~nm}$ were observed $(2.4(\sigma=0.1)$ and $1.5(\sigma=0.1)$, respectively) in 2008, as well as during the event in 2009 (2.3 $(\sigma=0.1)$ and $1.6(\sigma=0.1)$, respectively) (Ulevicius et al., 2010a). This is an indication of the influence of the biomass burning on the Ångström exponent of the absorption coefficient $\alpha$. The impact of organic aerosols on the spectral dependence of light absorption was already confirmed by the OC / EC ratios. PMF analysis of OA spectra resolved two OA components, which are attributed to POA and SOA, whose mass spectra and time series are presented in Fig. 5b, c. Combining these results with the ${ }^{14} \mathrm{C}$ measurements as described in Sect. 2.2.4 shows that the high grass burning pollution event is characterized by a high non-fossil organic compound fraction, which accounts for up to 90\% of total carbon mass.

SOA showed reasonable correlation $\left(R^{2}=0.62\right)$ with average $\mathrm{NH}_{4}^{+}$mass concentration during the $\mathrm{BB}$ event. $\mathrm{NH}_{4}^{+}$is in this case a good tracer for secondary aerosol, as it correlates well with the sum of $\mathrm{NO}_{3}^{-}$and $\mathrm{SO}_{4}^{2-}\left(R^{2}=0.96\right)$ (Fig. 6). There was day-to-day variation throughout the study period with the non-fossil contribution to organic carbon be- 

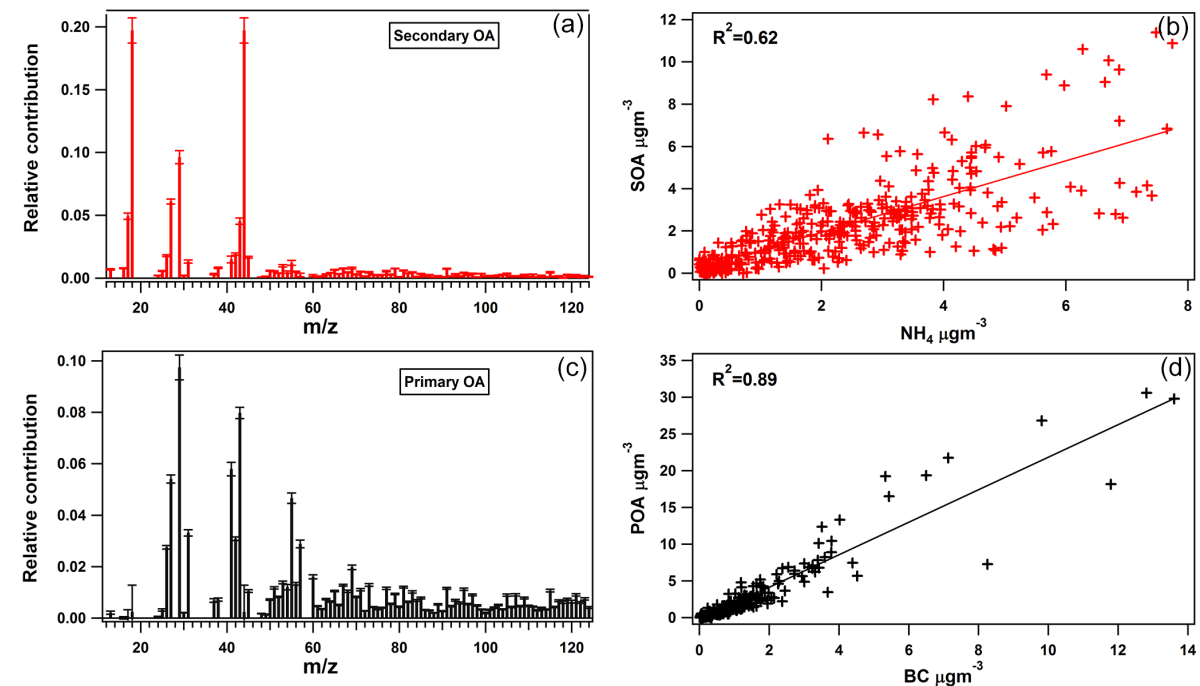

Figure 6. Mass spectra of SOA and POA, error bars represent the standard deviation of 20 PMF runs (a, c) and the scatter plots illustrate the relationship between $\mathrm{SOA}$ and $\mathrm{NH}_{4}^{+}$(b) and POA with $\mathrm{BC}(\mathbf{d})$.

Table 2. Variation of the fractions of $\mathrm{EC}_{\mathrm{f}}, \mathrm{EC}_{\mathrm{nf}}, \mathrm{OC}_{\mathrm{f}}, \mathrm{OC}_{\mathrm{nf}}$ and $\mathrm{TC}, \mathrm{EC}$ and $\mathrm{OC}$ values during the study periods.

\begin{tabular}{lccccccc}
\hline Date of collection & $\begin{array}{c}\mathrm{EC}_{\mathrm{f}} \\
\mu \mathrm{g} \mathrm{m}^{-3}\end{array}$ & $\begin{array}{c}\mathrm{EC}_{\mathrm{nf}} \\
\mu \mathrm{g} \mathrm{m}^{-3}\end{array}$ & $\begin{array}{c}\mathrm{OC}_{\mathrm{f}} \\
\mu \mathrm{g} \mathrm{m}^{-3}\end{array}$ & $\begin{array}{c}\mathrm{OC}_{\mathrm{nf}} \\
\mu \mathrm{g} \mathrm{m}^{-3}\end{array}$ & $\begin{array}{c}\mathrm{TC} \\
\mu \mathrm{g} \mathrm{m}^{-3}\end{array}$ & $\begin{array}{c}\mathrm{EC} \\
\mu \mathrm{g} \mathrm{m}^{-3}\end{array}$ & $\begin{array}{c}\mathrm{OC} \\
\mu \mathrm{g} \mathrm{m}^{-3}\end{array}$ \\
\hline 5 March 2014 & $0.25 \pm 0.04$ & 0.33 & $0.47 \pm 0.10$ & $2.34 \pm 0.18$ & $3.39 \pm 0.18$ & $0.59 \pm 0.17$ & $2.80 \pm 0.18$ \\
7 March 2014 & $0.21 \pm 0.04$ & 0.61 & $0.39 \pm 0.12$ & $2.80 \pm 0.20$ & $4.01 \pm 0.23$ & $0.81 \pm 0.24$ & $3.31 \pm 0.20$ \\
8 March 2014 & $0.15 \pm 0.05$ & 0.26 & $0.56 \pm 0.07$ & $1.46 \pm 0.12$ & $2.43 \pm 0.13$ & $0.41 \pm 0.18$ & $2.24 \pm 0.15$ \\
9 March 2014 & $0.46 \pm 0.16$ & 0.95 & $0.95 \pm 0.18$ & $4.98 \pm 0.36$ & $7.28 \pm 0.43$ & $1.36 \pm 0.63$ & $6.32 \pm 0.35$ \\
10 March 2014 & $0.56 \pm 0.18$ & 1.64 & $1.64 \pm 0.28$ & $7.77 \pm 0.50$ & $11.72 \pm 0.64$ & $2.31 \pm 0.75$ & $9.47 \pm 0.51$ \\
\hline
\end{tabular}

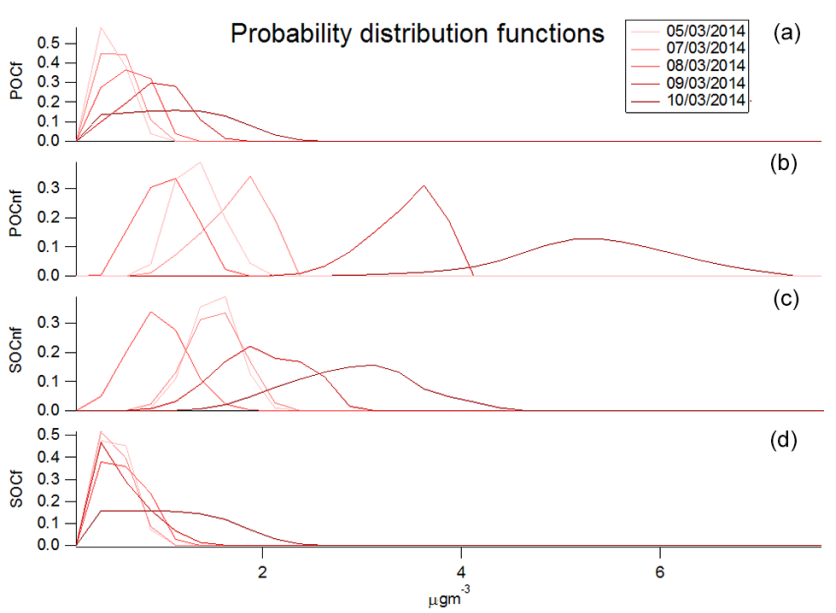

Figure 7. Probability distribution functions of the absolute daily contribution of $\mathrm{POC}_{\mathrm{f}}(\mathbf{a}), \mathrm{POC}_{\mathrm{nf}}(\mathbf{b}), \mathrm{SOC}_{\mathrm{nf}}(\mathbf{c}), \mathrm{SOC}_{\mathrm{f}}(\mathbf{d})$.

tween $67-86 \%$. $\mathrm{OC}_{\mathrm{nf}}$ was estimated to be $\sim 65 \%$ primary, while the primary fraction of the $\mathrm{OC}_{\mathrm{f}}$ in Preila was estimated to be $\sim 9 \%$. Conversely, when $\mathrm{EC}_{\mathrm{f}}$ showed a lower contribution (7 and 10 March 2014; 19 and 24\%, respectively), $\mathrm{OC}_{\mathrm{f}}$ was also lower (15\%) (Table 3). The high fraction of biomass burning was corroborated by measurements of levoglucosan. Other molecular markers such as hopanes for traffic emissions and picene for coal combustion (Rutter et al., 2009) were also measured in order to monitor the possible contribution of fossil fuel combustion during the high pollution event. Although their concentrations increased during the episode, suggesting a contribution of co-transported fossil fuel combustion aerosols, the radiocarbon analysis revealed the contribution of this fraction to be minor $\left(\mathrm{EC}_{\mathrm{f}}\right.$ ranged from 0.3 to $1.1 \mu \mathrm{g} \mathrm{m}^{-3} ; \mathrm{OC}_{\mathrm{f}}$ ranged from 0.5 to $1.6 \mu \mathrm{g} \mathrm{m}^{-3}$, Fig. 5). The concentrations of the molecular markers are provided in $\mathrm{Ta}-$ ble S1 of the Supplement. The combination of measurements and source apportionment techniques allowed a better characterization of the carbonaceous aerosol sources. POA determined with the ACSM is mostly non-fossil and originates from grass burning. It is shown that $\mathrm{POC}_{\mathrm{nf}}$ and $\mathrm{SOC}_{\mathrm{nf}}$ concentrations increase drastically (from 1.1 to $5.4 \mu \mathrm{g} \mathrm{m}^{-3}$ for $\mathrm{POC}_{\mathrm{nf}}$; from 0.9 to $3.1 \mu \mathrm{g} \mathrm{m}^{-3}$ for $\mathrm{SOC}_{\mathrm{nf}}$ ) with increasing influence of biomass burning, whereas the concentrations of the respective fossil fractions show a smaller increase during this episode. From the acceptable solutions obtained from the sensitivity test described in Sect. 2.2.5, we derived the prob- 
Table 3. Average percentage contributions of different sources.

\begin{tabular}{lccccccc}
\hline Relative contributions [\%] to TC & POC $_{\mathrm{f}}$ & $\mathrm{POC}_{\mathrm{nf}}$ & $\mathrm{SOC}_{\mathrm{f}}$ & $\mathrm{SOC}_{\mathrm{nf}}$ & $\mathrm{EC}_{\mathrm{f}}$ & $\mathrm{EC}_{\mathrm{nf}}$ & $\mathrm{TC}_{\text {to PM }}$ \\
\hline 5 March 2014 & 5.1 & 43.2 & 6.7 & 22.5 & 9.7 & 12.8 & 28.4 \\
7 March 2014 & 6.2 & 43.6 & 5.7 & 19.1 & 6.6 & 18.8 & 37.6 \\
8 March 2014 & 7.7 & 26.3 & 13.4 & 18.6 & 12.6 & 21.4 & 24.8 \\
9 March 2014 & 4.5 & 41.3 & 4.4 & 13.1 & 12.5 & 24.2 & 51.3 \\
10 March 2014 & 6.8 & 43.0 & 5.9 & 14.8 & 7.2 & 22.3 & 43.9 \\
\hline Relative contributions [\%] to OC & POC $_{\mathrm{f}}$ & POC $_{\mathrm{nf}}$ & $\mathrm{SOC}_{\mathrm{f}}$ & $\mathrm{SOC}_{\mathrm{nf}}$ & & & \\
\hline 5 March 2014 & 6.6 & 55.8 & 8.6 & 29.0 & & & \\
7 March 2014 & 8.4 & 58.4 & 7.6 & 25.6 & & & \\
8 March 2014 & 11.7 & 39.8 & 20.2 & 28.3 & & & \\
9 March 2014 & 7.2 & 65.2 & 6.9 & 20.7 & & & \\
10 March 2014 & 9.6 & 61.0 & 8.4 & 21.0 & & & \\
\hline
\end{tabular}

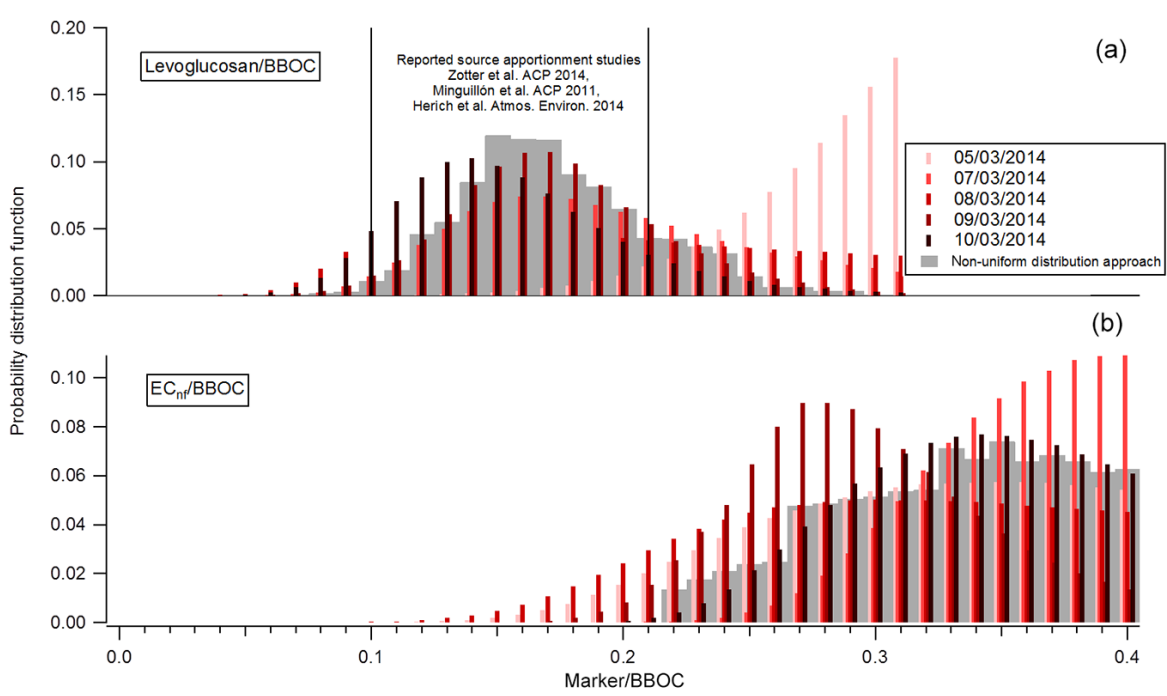

Figure 8. Please correct caption to: Probability distribution functions of Levoglucosan = BBOC (a) (Zotter et al., 2014; Minguillón et al., 2011; Herich et al., 2014) and $\mathrm{EC}_{\mathrm{nf}}=\mathrm{BBOC}(\mathbf{b})$.

ability distribution functions of the different daily contributions for the $\mathrm{POC}_{\mathrm{f}}, \mathrm{SOC}_{\mathrm{nf}}, \mathrm{SOC}_{\mathrm{f}}, \mathrm{POC}_{\mathrm{f}}$ fractions (Fig. 7). The median tests are consistent and EC / BBOC ratios obtained from the sensitivity tests are consistent with values reported in Zhang et al. (2015) and Huang et al. (2014) (Fig. 8).

In Zhang et al. (2015) agricultural waste combustion is considered to be the main contributor to the total biomass burning. Note that on 5 March a different Levoglucosan / BBOC ratio was found (0.31) compared to the nonevent days $(\sim 0.15)$. Also, this is consistent with different air mass back-trajectories, associated to air masses originating in the Southern and Central Russian Federal districts, i.e., air masses with a different geographical origin and associated to potentially different types of biomass burning.

\section{Conclusions}

In March 2014, an intensive field campaign was conducted in the marine background of the South-eastern Baltic region during a period of intensive grass burning. This paper provides the biomass burning related aerosol concentrations during grass burning estimated by data that stem from a synthesis of various techniques including surface online/offline and satellite-based measurements. Lidar vertical profiles allowed confirming smoke plumes from wild fire regions. Levels of source-specific tracers, i.e., levoglucosan as well as ${ }^{14} \mathrm{C}$ of TC, EC and OC were used as input for source apportionment of the carbonaceous aerosol. Overall, EC and OC were dominated by non-fossil sources. The total POC fraction was separated into $\mathrm{POC}_{\mathrm{f}}$ and $\mathrm{POC}_{\mathrm{nf}}$. In terms of OC mass, $\mathrm{POC}_{\mathrm{nf}}$ contributes on average $56 \%$, while the relative contribution to TC was found to be on average $39 \%$. In case of SOC, the 
contribution of $\mathrm{OC}_{\mathrm{f}}$ reached on average $10.3 \%$ (non-fossil $25 \%$ ). The $\delta^{13} \mathrm{C}$ value of $-28.5 \%$ indicated the dominance of the aerosol derived from the vegetation burning as no significant carbon isotope fractionation occurs between the aerosol particles from biomass burning and the raw biomass material.

\section{The Supplement related to this article is available online at doi:10.5194/acp-16-5513-2016-supplement.}

Acknowledgements. This work was supported by the LithuanianSwiss Cooperation Programme "Research and Development" project AEROLIT (Nr. CH-3-ك̌MM-01/08).

Edited by: W. Maenhaut

\section{References}

Agrios, K., Salazar, G. A., Zhang, Y. L., Uglietti, C., Battaglia, M., Luginbühl, M., Ciobanu, V. G., Vonwiller, M., and Szidat, S.: Online coupling of pure $\mathrm{O}_{2}$ thermo-optical methods ${ }^{14} \mathrm{C}$ AMS for source apportionment of carbonaceous aerosols study, Nucl. Instrum. Meth. Phys. Res. B., 361, 288-293, doi:10.1016/j.nimb.2015.06.008, 2015.

Aiken, A. C., Salcedo, D., Cubison, M. J., Huffman, J. A., DeCarlo, P. F., Ulbrich, I. M., Docherty, K. S., Sueper, D., Kimmel, J. R., Worsnop, D. R., Trimborn, A., Northway, M., Stone, E. A., Schauer, J. J., Volkamer, R. M., Fortner, E., de Foy, B., Wang, J., Laskin, A., Shutthanandan, V., Zheng, J., Zhang, R., Gaffney, J., Marley, N. A., Paredes-Miranda, G., Arnott, W. P., Molina, L. T., Sosa, G., and Jimenez, J. L.: Mexico City aerosol analysis during MILAGRO using high resolution aerosol mass spectrometry at the urban supersite (T0) - Part 1: Fine particle composition and organic source apportionment, Atmos. Chem. Phys., 9, 6633-6653, doi:10.5194/acp-9-6633-2009, 2009.

Akagi, S. K., Craven, J. S., Taylor, J. W., McMeeking, G. R., Yokelson, R. J., Burling, I. R., Urbanski, S. P., Wold, C. E., Seinfeld, J. H., Coe, H., Alvarado, M. J., and Weise, D. R.: Evolution of trace gases and particles emitted by a chaparral fire in California, Atmos. Chem. Phys., 12, 1397-1421, doi:10.5194/acp-12-13972012, 2012.

Baldini, G., Campadelli, P., and Fradegrada, M.: Biomass burning monitoring by scene analysis, In Proceedings of Visualization, Imaging, and Image Processing, Calgary, 2002.

Baron, P. A. and Willeke, K. (Eds.): Aerosol Measurement: Principles, Techniques, and Applications 2nd Edition, Wiley, New York, 2001.

Beddows, D. C. S., Dall'Osto, M., Harrison, R. M., Kulmala, M., Asmi, A., Wiedensohler, A., Laj, P., Fjaeraa, A. M., Sellegri, K., Birmili, W., Bukowiecki, N., Weingartner, E., Baltensperger, U., Zdimal, V., Zikova, N., Putaud, J.-P., Marinoni, A., Tunved, P., Hansson, H.-C., Fiebig, M., Kivekäs, N., Swietlicki, E., Lihavainen, H., Asmi, E., Ulevicius, V., Aalto, P. P., Mihalopoulos, N., Kalivitis, N., Kalapov, I., Kiss, G., de Leeuw, G., Henzing, B., O’Dowd, C., Jennings, S. G., Flentje, H., Meinhardt, F.,
Ries, L., Denier van der Gon, H. A. C., and Visschedijk, A. J. H.: Variations in tropospheric submicron particle size distributions across the European continent 2008-2009, Atmos. Chem. Phys., 14, 4327-4348, doi:10.5194/acp-14-4327-2014, 2014.

Bougiatioti, A., Stavroulas, I., Kostenidou, E., Zarmpas, P., Theodosi, C., Kouvarakis, G., Canonaco, F., Prévôt, A. S. H., Nenes, A., Pandis, S. N., and Mihalopoulos, N.: Processing of biomassburning aerosol in the eastern Mediterranean during summertime, Atmos. Chem. Phys., 14, 4793-4807, doi:10.5194/acp-144793-2014, 2014.

Byčenkiene, S., Ulevicius, V., and Kecorius, S.: Characteristics of black carbon aerosol mass concentration over the East Baltic region from two-year measurements, J. Environ. Monit., 13, 10271038, doi:10.1039/C0EM00480D, 2011.

Byčenkienè, S., Ulevicius, V., Dudoitis, V., and Pauraitè, J.: Identification and characterization of black carbon aerosol sources in the East Baltic region, Adv. Meteor., 2013, 380614, doi:10.1155/2013/380614, 2013.

Canonaco, F., Crippa, M., Slowik, J. G., Baltensperger, U., and Prévôt, A. S. H.: SoFi, an IGOR-based interface for the efficient use of the generalized multilinear engine (ME-2) for the source apportionment: ME-2 application to aerosol mass spectrometer data, Atmos. Meas. Tech., 6, 3649-3661, doi:10.5194/amt6-3649-2013, 2013.

Capes, G., Johnson, B., McFiggans, G., Williams, P. I., Haywood, J., and Coe, H.: Aging of biomass burning aerosols over West Africa: aircraft measurements of chemical composition, microphysical properties, and emission ratios, J. Geophys. Res.Atmos., 113, D00C15, doi:10.1029/2008JD009845, 2008.

Cavalli, F., Viana, M., Yttri, K. E., Genberg, J., and Putaud, J.-P.: Toward a standardised thermal-optical protocol for measuring atmospheric organic and elemental carbon: the EUSAAR protocol, Atmos. Meas. Tech., 3, 79-89, doi:10.5194/amt-3-79-2010, 2010.

Ceburnis, D., Garbaras, A., Szidat, S., Rinaldi, M., Fahrni, S., Perron, N., Wacker, L., Leinert, S., Remeikis, V., Facchini, M. C., Prevot, A. S. H., Jennings, S. G., Ramonet, M., and O'Dowd, C. D.: Quantification of the carbonaceous matter origin in submicron marine aerosol by ${ }^{13} \mathrm{C}$ and ${ }^{14} \mathrm{C}$ isotope analysis, Atmos. Chem. Phys., 11, 8593-8606, doi:10.5194/acp-11-85932011, 2011.

Collaud Coen, M., Weingartner, E., Apituley, A., Ceburnis, D., Fierz-Schmidhauser, R., Flentje, H., Henzing, J. S., Jennings, S. G., Moerman, M., Petzold, A., Schmid, O., and Baltensperger, U.: Minimizing light absorption measurement artifacts of the Aethalometer: evaluation of five correction algorithms, Atmos. Meas. Tech., 3, 457-474, doi:10.5194/amt-3-457-2010, 2010.

Crippa, M., Canonaco, F., Lanz, V. A., Äijälä, M., Allan, J. D., Carbone, S., Capes, G., Ceburnis, D., Dall'Osto, M., Day, D. A., DeCarlo, P. F., Ehn, M., Eriksson, A., Freney, E., Hildebrandt Ruiz, L., Hillamo, R., Jimenez, J. L., Junninen, H., Kiendler-Scharr, A., Kortelainen, A.-M., Kulmala, M., Laaksonen, A., Mensah, A. A., Mohr, C., Nemitz, E., O’Dowd, C., Ovadnevaite, J., Pandis, S. N., Petäjä, T., Poulain, L., Saarikoski, S., Sellegri, K., Swietlicki, E., Tiitta, P., Worsnop, D. R., Baltensperger, U., and Prévôt, A. S. H.: Organic aerosol components derived from 25 AMS data sets across Europe using a consistent ME-2 based source apportionment approach, Atmos. Chem. Phys., 14, 61596176, doi:10.5194/acp-14-6159-2014, 2014. 
Crutzen, P. J., Heidt, L. E., Krasnec, J. P., Pollock, W. H., and Seiler, W.: Biomass burning as a source of atmospheric gases $\mathrm{CO}, \mathrm{H}_{2}, \mathrm{~N}_{2} \mathrm{O}, \mathrm{NO}, \mathrm{CH}_{3} \mathrm{Cl}$, and COS, Nature, 282, 253-256, doi:10.1038/282253a0, 1979.

Currie, L. A.: Evolution and multidisciplinary frontiers of ${ }^{14} \mathrm{C}$ aerosol science, Radiocarbon, 42, 115-126, 2000.

Davison, A. C. and Hinkley, D. V.: Bootstrap Methods and Their Application, Cambridge University Press, Cambridge, UK, 582 pp., 1997.

EMEP (European Monitoring and Evaluation Programme), available at: http://www.emep.int/index.html, last access: 15 March 2015.

Fabbri, D., Torri, C., Simoneit, B., Marynowski, L., Rushdi, A., and Fabianska, M.: Levoglucosan and other cellulose and lignin markers in emissions from burning of Miocene lignites, Atmos. Environ., 43, 2286-2295, doi:10.1016/j.atmosenv.2009.01.030, 2009.

Fine, P. M., Cass, G. R., and Simoneit, B. R. T.: Chemical characterization of fine particle emissions from fireplace combustion of woods grown in the northeastern United States, Environ. Sci. Technol., 35, 2665-2675, doi:10.1021/es001466k, 2001.

Fine, P. M., Cass, G. R., and Simoneit, B. R. T.: Chemical characterization of fine particle emissions from the fireplace combustion of woods grown in the southern United States, Environ. Sci. Technol., 36, 1442-1451, doi:10.1021/es0108988, 2002.

Fine, P. M., Cass, G. R., and Simoneit, B. R. T.: Chemical characterization of fine particle emissions from the wood stove combustion of prevalent United States tree species, Environ. Eng. Sci., 21, 705-721, doi:10.1089/ees.2004.21.705, 2004a.

Fine, P. M., Cass, G. R., and Simoneit, B. R. T.: Chemical characterization of fine particle emissions fromfireplace combustion of woods grown in the Midwestern and Western United States, Environ. Eng. Sci., 21, 387-409, doi:10.1089/109287504323067021, 2004b.

Fröhlich, R., Crenn, V., Setyan, A., Belis, C. A., Canonaco, F., Favez, O., Riffault, V., Slowik, J. G., Aas, W., Aijälä, M., Alastuey, A., Artiñano, B., Bonnaire, N., Bozzetti, C., Bressi, M., Carbone, C., Coz, E., Croteau, P. L., Cubison, M. J., Esser-Gietl, J. K., Green, D. C., Gros, V., Heikkinen, L., Herrmann, H., Jayne, J. T., Lunder, C. R., Minguillón, M. C., Mocnik, G., O’Dowd, C. D., Ovadnevaite, J., Petralia, E., Poulain, L., Priestman, M., Ripoll, A., Sarda-Estève, R., Wiedensohler, A., Baltensperger, U., Sciare, J., and Prévôt, A. S. H.: ACTRIS ACSM intercomparison - Part 2: Intercomparison of ME-2 organic source apportionment results from 15 individual, co-located aerosol mass spectrometers, Atmos. Meas. Tech., 8, 2555-2576, doi:10.5194/amt8-2555-2015, 2015.

Garbaras, A., Andriejauskiene, J., Bariseviciute, R., and Remeikis, V.: Tracing of atmospheric aerosol sources using stable carbon isotopes, Lith. J. Phys., 48, 259-264, doi:10.3952/lithjphys.48309, 2008.

Garbaras, A., Masalaite, A., Garbariene, I., Ceburnis, D., Krugly, E., Remeikis, V., Puida, E., Kvietkus, K., and Martuzevicius, D.: Stable carbon fractionation in size segregated aerosol particles produced by controlled biomass burning, J. Aerosol Sci., 79, 8696, doi:10.1016/j.jaerosci.2014.10.005, 2015.

Grieshop, A. P., Logue, J. M., Donahue, N. M., and Robinson, A. L.: Laboratory investigation of photochemical oxidation of organic aerosol from wood fires 1: measurement and simulation of organic aerosol evolution, Atmos. Chem. Phys., 9, 1263-1277, doi:10.5194/acp-9-1263-2009, 2009.

Harrison, R. M., Beddows, D. C. S., Hu, L., and Yin, J.: Comparison of methods for evaluation of wood smoke and estimation of UK ambient concentrations, Atmos. Chem. Phys., 12, 82718283, doi:10.5194/acp-12-8271-2012, 2012.

Hawkins, L. N. and Russell, L. M.: Oxidation of ketone groups in transported biomass burning aerosol from the 2008 Northern California Lightning Series fires, Atmos. Environ., 44, 41424154, doi:10.1016/j.atmosenv.2010.07.036, 2010.

Hennigan, C. J., Sullivan, A. P., Collett Jr., J. L., and Robinson, A. L.: Levoglucosan stability in biomass burning particles exposed to hydroxyl radicals, Geophys. Res. Lett., 37, L09806, doi:10.1029/2010GL043088, 2010.

Herich, H., Gianini, M. F. D., Piot, C., Mocnik, G., Jaffrezo, J. L., Besombes, J. L., Prévôt, A. S. H., and Hueglin, C.: Overview of the impact of wood burning emissions on carbonaceous aerosols and PM in large parts of the Alpine region, Atmos. Environ., 89, 64-75, doi:10.1016/j.atmosenv.2014.02.008, 2014.

Heringa, M. F., DeCarlo, P. F., Chirico, R., Tritscher, T., Dommen, J., Weingartner, E., Richter, R., Wehrle, G., Prévôt, A. S. H., and Baltensperger, U.: Investigations of primary and secondary particulate matter of different wood combustion appliances with a high-resolution time-of-flight aerosol mass spectrometer, Atmos. Chem. Phys., 11, 5945-5957, doi:10.5194/acp-11-59452011, 2011.

Hildebrandt, L., Kostenidou, E., Lanz, V. A., Prevot, A. S. H., Baltensperger, U., Mihalopoulos, N., Laaksonen, A., Donahue, N. M., and Pandis, S. N.: Sources and atmospheric processing of organic aerosol in the Mediterranean: insights from aerosol mass spectrometer factor analysis, Atmos. Chem. Phys., 11, 1249912515, doi:10.5194/acp-11-12499-2011, 2011.

Hoffmann, D., Tilgner, A., Iinuma, Y., and Herrmann, H.: Atmospheric stability of levoglucosan: a detailed laboratory and modeling study, Environ. Sci. Technol., 44, 694-699, doi:10.1021/es902476f, 2010.

Honrath, R., Owen, R. C., Val Martin, M., Reid, J., Lapina, K., Fialho, P., Dziobak, M., Kleissl, J., and Westphal, D.: Regional and hemispheric impacts of anthropogenic and biomass burning missions on summertime $\mathrm{CO}$ and $\mathrm{O}_{3}$ in the North Atlantic lower free troposphere, J. Geophys. Res.-Atmos., 109, D24310, doi:10.1029/2004JD005147, 2004.

Huang, R.-J., Zhang, Y., Bozzetti, C., Ho, K.-F., Cao, J.-J., Han, Y., Daellenbach, K. R., Slowik, J. G., Platt, S. M., Canonaco, F., Zotter, P., Wolf, R., Pieber, S. M., Bruns, E. A., Crippa, M., Ciarelli, G., Piazzalunga, A., Schwikowski, M., Abbaszade, G., SchnelleKreis, J., Zimmermann, R., An, Z., Szidat, S., Baltensperger, U., El Haddad, I., and Prévôt, A. S. H.: High secondary aerosol contribution to particulate pollution during haze events in China, Nature, 514, 218-222, doi:10.1038/nature13774, 2014.

Jimenez, J. L., Canagaratna, M. R., Donahue, N. M., Prévôt, A. S. H., Zhang, Q., Kroll, J. H., DeCarlo, P. F., Allan, J. D., Coe, H., Ng, N. L., Aiken, A. C., Docherty, K. S., Ulbrich, I. M., Grieshop, A. P., Robinson, A. L., Duplissy, J., Smith, J. D., Wilson, K. R., Lanz, V. A., Hueglin, C., Sun, Y. L., Tian, J., Laaksonen, A., Raatikainen, T., Rautiainen, J., Vaattovaara, P., Ehn, M., Kulmala, M., Tomlinson, J. M., Collins, D. R., Cubison, M. J., Dunlea, E. J., Huffman, J. A., Onasch, T. B., Alfarra, M. R., Williams, P. I., Bower, K., Kondo, Y., Schnei- 
der, J., Drewnick, F., Borrmann, S., Weimer, S., Demerjian, K., Salcedo, D., Cottrell, L., Griffin, R., Takami, A., Miyoshi, T., Hatakeyama, S., Shimono, A., Sun, J. Y., Zhang, Y. M., Dzepina, K., Kimmel, J. R., Sueper, D., Jayne, J. T., Herndon, S. C., Trimborn, A. M., Williams, L. R., Wood, E. C., Middlebrook, A. M., Kolb, C. E., Baltensperger, U., and Worsnop, D. R.: Evolution of organic aerosols in the atmosphere, Science, 326, 1525-1529, doi:10.1126/science.1180353, 2009.

Kanamitsu, M., Ebisuzaki, W., Woollen, J., Yang, S. K., Hnilo, J. J., Fiorino, M., and Potter, G. L.: NCEP-DOE AMIPII reanalysis (R-2), B. Am. Meteorol. Soc., 83, 1631-1643, doi:10.1175/BAMS-83-11-1631, 2002.

Kikas, U., Reinart, A., Pugatshova, A., Tamm, E., and Ulevicius, V.: Microphysical, chemical and optical aerosol properties in the Baltic Sea region, Atmos. Res., 90, 211-222, doi:10.1016/j.atmosres.2008.02.009, 2008.

Lanz, V. A., Alfarra, M. R., Baltensperger, U., Buchmann, B., Hueglin, C., and Prévôt, A. S. H.: Source apportionment of submicron organic aerosols at an urban site by factor analytical modelling of aerosol mass spectra, Atmos. Chem. Phys., 7, 15031522, doi:10.5194/acp-7-1503-2007, 2007.

Lanz, V. A., Prévôt, A. S. H., Alfarra, M. R., Weimer, S., Mohr, C., DeCarlo, P. F., Gianini, M. F. D., Hueglin, C., Schneider, J., Favez, O., D'Anna, B., George, C., and Baltensperger, U.: Characterization of aerosol chemical composition with aerosol mass spectrometry in Central Europe: an overview, Atmos. Chem. Phys., 10, 10453-10471, doi:10.5194/acp-10-10453-2010, 2010.

Lavanchy, V. M. H., Gäggeler, H. W., Schotterer, U., Schwikowski, M., and Baltensperger, U.: Historical record of carbonaceous particle concentrations from a European high-alpine glacier (Colle Gnifetti, Switzerland), J. Geophys. Res.-Atmos., 104, $21227-$ 21236, doi:10.1029/1999jd900408, 1999.

Lemire, K. R., Allen, D. T., Klouda, G. A., and Lewis, C. W.: Fine particulate matter source attribution for southeast Texas using ${ }^{14} \mathrm{C} /{ }^{13} \mathrm{C}$ ratios, J. Geophys. Res., 107, 4613, doi:10.1029/2002JD002339, 2002.

Levine, J. S.: Biomass Burning And Global Change, Cambridge, MA, MIT Press, 1996

Lewis, C. W., Klouda, G. A., and Ellenson, W. D.: Radiocarbon measurement of the biogenic contribution to summertime PM-2.5 ambient aerosol in Nashville, TN, Atmos. Environ., 38, 6053-6061, doi:10.1016/j.atmosenv.2004.06.011, 2004.

Mann, G. W., Carslaw, K. S., Reddington, C. L., Pringle, K. J., Schulz, M., Asmi, A., Spracklen, D. V., Ridley, D. A., Woodhouse, M. T., Lee, L. A., Zhang, K., Ghan, S. J., Easter, R. C., Liu, X., Stier, P., Lee, Y. H., Adams, P. J., Tost, H., Lelieveld, J., Bauer, S. E., Tsigaridis, K., van Noije, T. P. C., Strunk, A., Vignati, E., Bellouin, N., Dalvi, M., Johnson, C. E., Bergman, T., Kokkola, H., von Salzen, K., Yu, F., Luo, G., Petzold, A., Heintzenberg, J., Clarke, A., Ogren, J. A., Gras, J., Baltensperger, U., Kaminski, U., Jennings, S. G., O'Dowd, C. D., Harrison, R. M., Beddows, D. C. S., Kulmala, M., Viisanen, Y., Ulevicius, V., Mihalopoulos, N., Zdimal, V., Fiebig, M., Hansson, H.-C., Swietlicki, E., and Henzing, J. S.: Intercomparison and evaluation of global aerosol microphysical properties among AeroCom models of a range of complexity, Atmos. Chem. Phys., 14, 4679-4713, doi:10.5194/acp-14-4679-2014, 2014

Masalaite, A., Remeikis, V., Garbaras, A., Dudoitis, V., Ulevicius, V., and Ceburnis, D.: Elucidating carbonaceous aerosol sources by the stable carbon $\delta^{13} \mathrm{C}$ TC ratio in size-segregated particles, Atmos. Res., 158-159, 1-12, doi:10.1016/j.atmosres.2015.01.014, 2015.

Matthew, B. M., Middlebrook, A. M., and Onasch, T. B.: Collection efficiencies in an Aerodyne eerosol mass spectrometer as a function of particle phase for laboratory generated aerosols, Aerosol Sci. Tech., 42, 884-898, doi:10.1080/02786820802356797, 2008.

Middlebrook, A. M., Bahreini, R., Jimenez, J. L., and Canagaratna, M. R.: Evaluation of composition-dependent collection efficiencies for the Aerodyne aerosol mass spectrometer using field data, Aerosol Sci. Tech., 46, 258-271, doi:10.1080/02786826.2011.620041, 2012.

Minguillón, M. C., Perron, N., Querol, X., Szidat, S., Fahrni, S. M., Alastuey, A., Jimenez, J. L., Mohr, C., Ortega, A. M., Day, D. A., Lanz, V. A., Wacker, L., Reche, C., Cusack, M., Amato, F., Kiss, G., Hoffer, A., Decesari, S., Moretti, F., Hillamo, R., Teinilä, K., Seco, R., Peñuelas, J., Metzger, A., Schallhart, S., Müller, M., Hansel, A., Burkhart, J. F., Baltensperger, U., and Prévôt, A. S. H.: Fossil versus contemporary sources of fine elemental and organic carbonaceous particulate matter during the DAURE campaign in Northeast Spain, Atmos. Chem. Phys., 11, 12067-12084, doi:10.5194/acp-11-12067-2011, 2011.

Mochida, M., Kawamura, K., Fu, P. Q., and Takemura, T.: Seasonal variation of levoglucosan in aerosols over the western North Pacific and its assessment as a biomass-burning tracer, Atmos. Environ., 44, 3511-3518, doi:10.1016/j.atmosenv.2010.06.017, 2010.

MODIS NASA LANCE: FIRMS, MODIS Active Fire Detections, Data set, available at: https://earthdata.nasa.gov/ earth-observation-data/near-real-time/firms (last access: 10 May 2014), 2011.

Mohn, J., Szidat, S., Fellner, J., Rechberger, H., Quartier, R., Buchmann, B., and Emmenegger, L.: Determination of biogenic and fossil $\mathrm{CO}_{2}$ emitted by waste incineration based on ${ }^{14} \mathrm{CO}_{2}$ and mass balances, Bioresour. Technol., 99, 6471-6479, 2008.

Mohr, C., Huffman, J. A., Cubison, M. J., Aiken, A. C., Docherty, K. S., Kimmel, J. R., Ulbrich, I. M., Hannigan, M., and Jimenez, J. L.: Characterization of Primary Organic Aerosol 25 Emissions from Meat Cooking, Trash Burning, and Motor Vehicles with High-Resolution Aerosol Mass Spectrometry and Comparison with Ambient and Chamber Observations, Environ. Sci. Technol., 43, 2443-2449, doi:10.1021/es8011518, 2009.

Mordas, G., Ulevicius, V., Plauškaitè, K., and Prokopčiuk, N.: Validation of the condensation particle counter UF-02M in laboratory and ambient conditions, Lith. J. Phys., 53, 175-182, 2013.

Ng, N. L., Herndon, S. C., Trimborn, A., Canagaratna, M. R. Croteau, P. L., Onasch, T. B. Sueper, D., Worsnop, D. R., Zhang, Q., Sun, Y. L., and Jayne, J. T.: An Aerosol Chemical Speciation Monitor (ACSM) for routine monitoring of the composition and mass concentrations of ambient aerosol, Aerosol Sci. Tech., 45, 770-784, doi:10.1080/02786826.2011.560211, 2011.

Oanh, N. T. K., Ly, B. T., Tipayarom, D., Manandhar, B. R., Prapat, P., Simpson, C. D., and Liu, L. J. S.: Characterization of particulate matter emission from open burning of rice straw, Atmos. Environ., 45, 493-502, doi:10.1016/j.atmosenv.2010.09.023, 2011.

Orasche, J., Schnelle-Kreis, J., Abbaszade, G., and Zimmermann, R.: Technical Note: In-situ derivatization thermal desorption GC-TOFMS for direct analysis of particle-bound non-polar and 
polar organic species, Atmos. Chem. Phys., 11, 8977-8993, doi:10.5194/acp-11-8977-2011, 2011.

Orasche, J., Seidel, T., Hartmann, H., Schnelle-Kreis, J., Chow, J. C, Ruppert, H., and Zimmermann R.: Comparison of emissions from wood combustion. Part 1: Emission factors and characteristics from different small-scale residential heating appliances considering particulate matter and polycyclic aromatic hydrocarbon (PAH)-related toxicological potential of particle-bound organic species, Energy Fuels, 26, 6695-6704, doi:10.1021/ef301295k, 2012.

Oros, D. R., Radzi bin Abas, M., Omar, N. Y. M. J., Rahman, N. A., and Simoneit, B. R. T.: Identification and emission factors of molecular tracers in organic aerosols from biomass burning: 3. Grasses, Appl. Geochem., 21, 919-940, doi:10.1016/j.apgeochem.2006.01.008, 2006.

Paatero, P.: Least squares formulation of robust non-negative factor analysis, Chemometr. Intell. Lab., 37, 23-35, doi:10.1016/S0169-7439(96)00044-5, 1997.

Paatero, P. and Tapper, U.: Positive matrix factorization a nonnegative factor model with optimal utilization of error-estimates of data values, Environmetrics, 5, 111-126, doi:10.1002/env.3170050203, 1994.

Paatero, P., Eberly, S., Brown, S. G., and Norris, G. A.: Methods for estimating uncertainty in factor analytic solutions, Atmos. Meas. Tech., 7, 781-797, doi:10.5194/amt-7-781-2014, 2014.

Popovicheva, O., Kistler, M., Kireeva, E., Persiantseva, N., Timofeev, M., Kopeikin, V., and Kasper-Giebl, A.: Physicochemical characterization of smoke aerosol during large-scale wildfires: extreme event of August 2010 in Moscow, Atmos. Environ., 96, 405-414, doi:10.1016/j.atmosenv.2014.03.026, 2014.

Puxbaum, H., Caseiro, A., Sánchez-Ochoa, A., Kasper-Giebl, A., Claeys, M., Gelencsér, A., Legrand, M., Preunkert, S., and Pio, C.: Levoglucosan levels at background sites in Europe for assessing the impact of biomass combustion on the European aerosol background, J. Geophys. Res., 112, D23S05, doi:10.1029/2006JD008114, 2007.

Reid, J. S., Prins, E. M., Westphal, D. L., Schmidt, C. C., Richardson, K. A., Christopher, S. A., Eck, T. F., Reid, E. A., Curtis, C. A., and Hoffman, J. P.: Real-time monitoring of South American smoke particle emissions and transport using a coupled remote sensing/box-model approach, Geophys. Res. Lett., 31, L06107, doi:10.1029/2003GL018845, 2004.

Rutter, A. P., Snyder, D. C., Schauer, J. J., DeMinter, J., and Shelton, B.: Sensitivity and bias of molecular marker-based aerosol source apportionment models to small contributions of coal combustion soot, Environ. Sci. Technol., 43, 7770-7777, 2009.

Saarikoski, S., Sillanpaa, M., Sofiev, M., Timonen, H., Saarnio, K., Teinela, K., Karppinen, A., Kukkonen, J., and Hillamo, R.: Chemical composition of aerosols during a major biomass burning episode over northern Europe in spring 2006: Experimental and modelling assessments, Atmos. Environ., 41, 3577-3589, doi:10.1016/j.atmosenv.2006.12.053, 2007.

Salazar, G., Zhang, Y. L., Agrios, K., and Szidat, S.: Development of a method for fast and automatic radiocarbon measurement of aerosol samples by online coupling of an elemental analyzer with a MICADAS AMS, Nucl. Instrum. Meth. Phys. Res. B., 361, 163-167, doi:10.1016/j.nimb.2015.03.051, 2015.

Schmidl, C., Marr, I. L., Caseiro, A., Kotianová, P., Berner, A., Bauer, H., Kasper-Giebl, A., and Puxbaum, H.: Chemical charac- terisation of fine particle emissions from wood stove combustion of common woods growing in mid-European Alpine regions, Atmos. Environ., 42, 126-141, 2008.

Sofiev, M., Siljamo, P., Valkama, I., Ilvonen, M., and Kukkonen, J.: A dispersion modelling system SILAM and its evaluation against ETEX data, Atmos. Environ., 40, 674-685, doi:10.1016/j.atmosenv.2005.09.069, 2006.

Stein, A. F., Draxler, R. R., Rolph, G. D., Stunder, B. J. B., Cohen, M. D., and Ngan, F.: NOAA's HYSPLIT atmospheric transport and dispersion modeling system, B. Amer. Meteor. Soc., 96, 2059-2077, 2015.

Sullivan, A. P., Holden, A. S., Patterson, L. A., McMeeking, G. R., Kreidenweis, S. M., Malm, W. C., Hao, W. M., Wold, C. E., and Collett Jr., J. L.: A method for smoke marker measurements and its potential application for determining the contribution of biomass burning from wildfires and prescribed fires to ambient PM2.5 organic carbon, J. Geophys. Res., 113, D22302, doi:10.1029/2008JD010216, 2008.

Sullivan, A. P., May, A. A., Lee, T., McMeeking, G. R., Kreidenweis, S. M., Akagi, S. K., Yokelson, R. J., Urbanski, S. P., and Collett Jr., J. L.: Airborne characterization of smoke marker ratios from prescribed burning, Atmos. Chem. Phys., 14, 1053510545, doi:10.5194/acp-14-10535-2014, 2014.

Sun, Y. L., Wang, Z. F., Dong, H. B., Yang, T., Li, J., Pan, X. L., Chen, P., and Jayne, J. T.: Characterization of summer organic and inorganic aerosols in Beijing, China with an aerosol chemical speciation monitor, Atmos. Environ., 51, 250-259, doi:10.1016/j.atmosenv.2012.01.013, 2012.

Szidat, S., Jenk, T. M., Gäggeler, H. W., Synal, H.-A., Fisseha, R., Baltensperger, U., Kalberer, M., Samburova, V., Reimann, S., Kasper-Giebl, A., and Hajdas, I.: Radiocarbon $\left({ }^{14} \mathrm{C}\right)$-deduced biogenic and anthropogenic contributions to organic carbon (OC) of urban aerosols from Zurich, Switzerland, Atmos. Environ., 38, 4035-4044, doi:10.1016/j.atmosenv.2004.03.066, 2004.

Szidat, S., Salazar, G. A., Vogel, E., Battaglia, M., Wacker, L., Synal, H.-A., and Türler, A.: ${ }^{14} \mathrm{C}$ analysis and sample preparation at the new Bern Laboratory for the Analysis of Radiocarbon with AMS (LARA), Radiocarbon, 56, 561-566, doi:10.2458/56.17457, 2014.

Timonen, H., Aurela, M., Carbone, S., Saarnio, K., Saarikoski, S., Mäkelä, T., Kulmala, M., Kerminen, V.-M., Worsnop, D. R., and Hillamo, R.: High time-resolution chemical characterization of the water-soluble fraction of ambient aerosols with PILS-TOC-IC and AMS, Atmos. Meas. Tech., 3, 1063-1074, doi:10.5194/amt-3-1063-2010, 2010.

Turekian, V. C., Macko, S., Ballentine, D., Swap, R. J., and Garstang, M.: Causes of bulk carbon and nitrogen isotopic fractionations in the products of vegetation burns: laboratory studies, Chem. Geol., 152, 181-192, doi:10.1016/S00092541(98)00105-3 1998.

Ulbrich, I. M., Canagaratna, M. R., Zhang, Q., Worsnop, D. R., and Jimenez, J. L.: Interpretation of organic components from Positive Matrix Factorization of aerosol mass spectrometric data, Atmos. Chem. Phys., 9, 2891-2918, doi:10.5194/acp-9-2891-2009, 2009.

Ulevicius, V., Byčenkienė, S., Remeikis, V., Garbaras, A., Kecorius, S., Andriejauskienè, J., Jasinevičienè, D., and Močnik, G.: Characterization of aerosol particle episodes in Lithuania caused 
by long-range and regional transport, Atmos. Res., 98, 190-200, doi:10.1016/j.atmosres.2010.03.021, 2010a.

Ulevicius, V., Byčenkienė, S., Špirkauskaitè, N., and Kecorius, S.: Biomass burning impact on black carbon aerosol mass concentration at a coastal site: case studies, Lith. J. Phys., 50, 335-344, doi:10.3952/lithjphys.50304, 2010b.

Weimer, S., Alfarra, M. R., Schreiber, D., Mohr, M., Prévôt, A. S. H., and Baltensperger U.: Organic aerosol mass spectral signatures from wood burning emissions: Influence of burning conditions and wood type, J. Geophys. Res., 113, D10304, doi:10.1029/2007JD009309, 2008.

Widory, D.: Nitrogen isotopes: Tracers of origin and processes affecting $\mathrm{PM}_{10}$ in the atmosphere of Paris, Atmos. Environ., 41, 2382-2390, doi:10.1016/j.atmosenv.2006.11.009, 2007.

Wiedensohler, A., Birmili, W., Nowak, A., Sonntag, A., Weinhold, K., Merkel, M., Wehner, B., Tuch, T., Pfeifer, S., Fiebig, M., Fjäraa, A. M., Asmi, E., Sellegri, K., Depuy, R., Venzac, H., Villani, P., Laj, P., Aalto, P., Ogren, J. A., Swietlicki, E., Williams, P., Roldin, P., Quincey, P., Hüglin, C., Fierz-Schmidhauser, R., Gysel, M., Weingartner, E., Riccobono, F., Santos, S., Grüning, C., Faloon, K., Beddows, D., Harrison, R., Monahan, C., Jennings, S. G., O’Dowd, C. D., Marinoni, A., Horn, H.-G., Keck, L., Jiang, J., Scheckman, J., McMurry, P. H., Deng, Z., Zhao, C. S., Moerman, M., Henzing, B., de Leeuw, G., Löschau, G., and Bastian, S.: Mobility particle size spectrometers: harmonization of technical standards and data structure to facilitate high quality long-term observations of atmospheric particle number size distributions, Atmos. Meas. Tech., 5, 657-685, doi:10.5194/amt5-657-2012, 2012.

Yttri, K. E., Simpson, D., Nøjgaard, J. K., Kristensen, K., Genberg, J., Stenström, K., Swietlicki, E., Hillamo, R., Aurela, M., Bauer, H., Offenberg, J. H., Jaoui, M., Dye, C., Eckhardt, S., Burkhart, J. F., Stohl, A., and Glasius, M.: Source apportionment of the summer time carbonaceous aerosol at Nordic rural background sites, Atmos. Chem. Phys., 11, 13339-13357, doi:10.5194/acp11-13339-2011, 2011.
Yttri, K. E., Lund Myhre, C., Eckhardt, S., Fiebig, M., Dye, C., Hirdman, D., Ström, J., Klimont, Z., and Stohl, A.: Quantifying black carbon from biomass burning by means of levoglucosan - a one-year time series at the Arctic observatory Zeppelin, Atmos. Chem. Phys., 14, 6427-6442, doi:10.5194/acp-14-64272014, 2014.

Zawadzka, O., Makuch, P., Markowicz, K. M., Zieliński, T., Petelski, T., Ulevicius, V., Strzałkowska, A., Rozwadowska, A., and Gutowska, D.: Studies of aerosol optical depth with the use of microtops II sun photometers and MODIS detectors in coastal areas of the Baltic Sea, Acta Geophys., 62, 400-422, doi:10.2478/s11600-013-0182-5, 2013.

Zhang, Y. L., Perron, N., Ciobanu, V. G., Zotter, P., Minguillón, M. C., Wacker, L., Prévôt, A. S. H., Baltensperger, U., and Szidat, S.: On the isolation of OC and EC and the optimal strategy of radiocarbon-based source apportionment of carbonaceous aerosols, Atmos. Chem. Phys., 12, 10841-10856, doi:10.5194/acp-12-10841-2012, 2012.

Zhang, Y.-L., Huang, R.-J., El Haddad, I., Ho, K.-F., Cao, J.-J., Han, Y., Zotter, P., Bozzetti, C., Daellenbach, K. R., Canonaco, F., Slowik, J. G., Salazar, G., Schwikowski, M., Schnelle-Kreis, J., Abbaszade, G., Zimmermann, R., Baltensperger, U., Prévôt, A. S. H., and Szidat, S.: Fossil vs. non-fossil sources of fine carbonaceous aerosols in four Chinese cities during the extreme winter haze episode of 2013, Atmos. Chem. Phys., 15, 1299-1312, doi:10.5194/acp-15-1299-2015, 2015.

Zotter, P., Ciobanu, V. G., Zhang, Y. L., El-Haddad, I., Macchia, M., Daellenbach, K. R., Salazar, G. A., Huang, R.-J., Wacker, L., Hueglin, C., Piazzalunga, A., Fermo, P., Schwikowski, M., Baltensperger, U., Szidat, S., and Prévôt, A. S. H.: Radiocarbon analysis of elemental and organic carbon in Switzerland during winter-smog episodes from 2008 to 2012 - Part 1: Source apportionment and spatial variability, Atmos. Chem. Phys., 14, 1355113570, doi:10.5194/acp-14-13551-2014, 2014. 